\title{
A APROPIACIÓN SIMBÓLICA DA CULTURA MATE- RIAL CASTREXA NA PAISAXE CULTURAL DOS CHAOS DE AMOEIRO (OURENSE, GALICIA)*
}

\author{
ARIZAGA CASTRO, ÁLVARO R. ${ }^{1}$ - FÁBREGA ÁLVAREZ, PASTOR ${ }^{2}$ \\ AYÁN VILA, XURXO M. ${ }^{2}$ - RODRÍGUEZ PAZ, ANXO ${ }^{3}$
}

\begin{abstract}
Resumen
Se presentan una serie de hallazgos de cultura material en la provincia de Ourense (Galicia), relativamente descontextualizados pero cuyo origen podemos remontar en algunos casos a la protohistoria. Al mismo tiempo, se discuten algunos de los problemas de la arqueología de la Edad del Hierro en la región, así como los procesos de reutilización popular que han permitido la conservación de las piezas.
\end{abstract}

\section{Palabras clave}

Chaos de Amoeiro. Edad del Hierro. Cultura material. Reutilización popular.

\begin{abstract}
We present some new finds from Ourense (Galicia), not exactly with archaeological context but some of them surely belonging to a protohistoric origin. We also discuss some questions about regional iron age and explain the process of reutilization in traditional culture.
\end{abstract}

\section{Key Words}

Chaos de Amoeiro. Iron Age. Finds. Popular reutilization.

\footnotetext{
* Entregado o 7 de Abril de 2006. As figuras deste artigo están dispoñibles a mellor calidade na páxina web www-gtarpa. usc.es

${ }^{1}$ Departamento de Historia I, Facultade de Xeografía, Historia e Arte - USC.

${ }^{2}$ Laboratorio de Arqueoloxía do IEGPS-CSIC-XuGa.

${ }^{3}$ Laboratorio de Arqueoloxía do IEGPS-CSIC-XuGa. Debuxante.
} 
Pra mostrar quererme ben dáme bon viño de Leiro, pantrigo de Ribadavia, mozas do Chao de Amoeiro.

(OTERO 1974: 60)

Agradecementos: O medio campesiño e rural dos Chaos é o protagonista deste artigo, ou iso pretendemos. É por iso que este artigo está adicado a todas aquelas persoas que nos axudaron e nos deron a coñecer o seu patrimonio, en Amoeiro, no Formigueiro, en San Xiao, en Albeiros, en Anllo, en tantos sitios. Eles non son o obxecto da nosa investigación: son os nosos mestres. A todos eles, grazas.

Grazas tamén a Nieves Amado, Rafael e Adolfo Otero, Rebeca Blanco e Sonia García, que nos deron a coñecer as pedras reutilizadas en Anllo. Grazas, por último, a César Parcero pola revisión deste texto.

\section{INTRODUCIÓN 4}

No contexto do actual debate arqueolóxico a escala mundial resulta redundante defender un postulado fundamental da alcumada arqueoloxía postprocesual ou contextual, como é o feito de que a cultura material non é un mero reflexo das sociedades do presente e do pasado, senón que constitúe unha ferramenta de primeira orde na construción da realidade social, desempeñando un rol activo na definición das identidades, sobre todo nos grupos premodernos e nas sociedades campesiñas «tradicionais». Sen embargo, o peso dunha tradición arqueográfica pseudopositivista e para-funcionalista no caso galego, obriga a facer fincapé en obviedades deste estilo.

Tanto os límicos da Idade do Ferro coma os labregos da Limia Baixa do antigo réxime, por poñer un exemplo, constitúen grupos humanos que reflectiron o seu patrón de racionalidade a través da oralidade e dun inmenso aparello icónico-visual composto polo espazo doméstico, polas cadeas técnico-operativas empregadas na construción do espazo e da arquitectura, da cerámica e da paisaxe, pola súa forma, en definitiva, de estaren no mundo. Esta produción continua de cultura material no

\footnotetext{
${ }^{4}$ Este traballo se vincula ao proxecto de investigación: De la protohistoria a la romanización: interacción cultural y dinámica del territorio en el norte de la provincia de Pontevedra (PGIDIT05PXIA23601PR), dirixido por F. J. González García (investigador principal), Plan Xeral de I+D da Xunta de Galicia (2002-2005).
} 
presente vivo desas comunidades, combínase con outro proceso presente sempre en toda comunidade, como é a xestión do tempo, a xestión cultural das evidencias dun pasado alleo, a reinterpretación e reutilización simbólica dos restos materiais das formacións sociais pretéritas.

Esta dobre relación de construción do espazo e de reinterpretación do tempo que se dá na sociedade pode ser abordada dende a disciplina etnoarqueolóxica, combinando a aproximación á cultura material propia da Arqueoloxía coa perspectiva diacrónica, tan pouco tratada pola Antropoloxía convencional.

A este respecto, dende este enfoque etnoarqueolóxico, vimos traballando nos últimos anos nunha liña de investigación que afonda neses procesos de apropiación simbólica dos restos materiais do pasado, da idade do ferro máis concretamente, por parte das nosas comunidades campesiñas e mariñeiras tradicionais (Ayán 2005, Ayán 2005a, Ayán e Arizaga 2005, Arizaga e Ayán, no prelo). A apropiación simbólica dos castros por parte do campesiñado e do estamento eclesiástico en Galicia dende a época altomedieval, compleméntase con outro proceso non menos interesante pero apenas atendido dende a arqueoloxía como é a reutilización de elementos da cultura material castrexa na arquitectura rural.

Neste senso, ten sido unha práctica común en todo o país o reaproveitamento por parte dos paisanos das nosas aldeas do material lítico procedente de xacementos arqueolóxicos como castros e castelos arruinados. Non obstante, cremos que nalgúns casos esta reutilización non resposta unicamente a criterios economicistas de maximización de recursos e minimización de custes no que á construción se refire, senón que se pode falar dunha apropiación consciente que leva, nalgúns casos, a unha utilización intencional deses elementos en edificacións de carácter ritual, como capelas ou igrexas. Como exemplo significativo deste proceso esbozamos os resultados dun traballo etnoarqueolóxico realizado na zona de Chaos de Amoeiro, próxima á cidade de Ourense. O traballo de prospección e, sobre todo, a enquisa etnográfica, permitiron documentar toda unha serie de elementos ornamentais en pedra reutilizados nunha serie de aldeas que, no caso do concello de Amoeiro, se dispoñen en torno ó Coto do Castelo, onde é posible situar hipoteticamente un poboado fortificado hoxe desaparecido debido á explotación dunha canteira tradicional, fonte de aprovisionamento de materiais líticos para a construción nesta rexión. O carácter xeneralizado desta apropiación da cultura material castrexa nesta zona de Chaos de Amoeiro constitúe un fenómeno que supera un mero aproveitamento circunstancial da arte da Idade do Ferro $^{5}$, e lévanos a plantexarnos cuestións

\footnotetext{
${ }^{5}$ Cómpre sinalar que boa parte da investigación sobre a arte castrexa do NW, segue considerando, secundando os polémicos traballos de F. Calo Lourido (1994: 816-826) que toda a arte castrexa
} 
como a perduración deses motivos decorativos no románico rural, a existencia dunha valoración positiva popular da estética castrexa ou a súa plasmación en estratexias de cristianización do territorio, coa súa inclusión en capelas de carácter popular - e non tanto en igrexas parroquiais «oficiais».

Dentro dese contexto, neste artigo presentaremos unha serie de novos achados, ó tempo que tentamos dar unha interpretación dos procesos que permitiron a súa conservación, é dicir, a reutilización popular arquitectónica da cultura material na sociedade campesiña tradicional. Ademais proporemos unha breve análise comparativa con algúns poucos paralelos formais i estilísticos dos achados. Ante o descoñecemento da posición orixinaria das pezas ${ }^{6}$, adoptamos unha estratexia metodolóxica baseada na contextualización etnográfica e arqueo-xeográfica do entorno, co obxectivo de tentar aproximarnos o sentido orixinal desempeñado. Este texto nace fondamente ligado a unha investigación conxunta, artellada dende a arqueoloxía da paisaxe no estudo territorial da Idade do Ferro no noroeste peninsular.

Como quedará patente ó longo do artigo, a investigación segue en curso e os resultado son, aínda, preliminares. Nembargantes, cremos que é tempo de presentar esta publicación, dado o interese dos novos achados e a pertinencia das hipóteses e debates sobre a Idade do Ferro na zona. O noso discurso comeza debatendo o estado xeral da investigación sobre a Idade do Ferro na comarca, para explicar o contexto problemático no que se insire a nosa investigación. Centrámonos despois na contundente excepcionalidade dos achados e no fenómeno popular da reutilización da cultura material.

En canto ó que pode ser o aspecto máis polémico deste artigo, a adscrición crono-cultural dos achados, abordamos a súa análise conscientes do problema do concepto «tipoloxía castrexa» e dos debates sobre a súa cronoloxía. Pensamos que se pode falar dunha «tipoloxía castrexa» ligada ou relacionada cos castros e coa cultura indíxena prerromana, aínda que tamén se poida desenvolver en períodos posteriores da historia. Nas cerámicas, na arte escultórica, na tipoloxía do asentamento, existen unha serie de parámetros que se poden considerar «indíxenas» e «castrexos»: pensamos que boa parte das pezas que presentamos a continuación

\footnotetext{
-coma carente de trasfondo simbólico ou relixioso- debe encadrarse no período inmediatamente posterior á conquista, s. I d. C. (Sastre 2004: 6). Non deixa de ser curioso que se considere como exemplo do impacto da romanización unha estatuaria formalmente indíxena que representa claramente temas e motivos formais bastante alleos á estética romana.

${ }^{6} \mathrm{O}$ que non quer dicir que as pezas carezan de contexto, como moitas veces adoitamos laiarnos os arqueólogos cando os materiais cos que traballamos non proceden dun xacemento. Este caso é un perfecto exemplo de materiais contextualizados, malia que ese contexto non sexa o da súa produción e uso primixenios.
} 
forman parte deste horizonte, mesmo tendo en conta as lóxicas reticencias que amosa para moitas pezas supostamente «castrexas» Calo Lourido (1994: 703-4) e sen poder desentrañar a exacta cronoloxía das mesmas ${ }^{7}$.

\section{CARACTERIZACIÓN XEOGRÁFICA I ETNOGRÁFICA DA ZONA DE ESTUDO: OS CHAOS DE AMOEIRO}

Sobre os Chaos de Amoeiro como territorio non se teñen publicado demasiados artigos académicos. Destacan algúns traballos, poucos pero substanciosos, de Otero Pedrayo, sobre todo o seu «pequeno estudo da parroquia de Trasalba escolmada como terreo d'esprencia» (Otero 1927-8; n. ${ }^{\circ}$ 53: 95), que constitúe unha magnífica descrición xeográfica pero tamén etnográfica, na mellor tradición do Seminario de Estudos Galegos.

Os Chaos de Amoeiro teñen sido comunmente considerados unha rexión «perfectamente» individualizada, quizais unha das comarcas naturais máis «evidentes» de Galicia. E, sen embargo, a súa delimitación presenta problemas non menores, porque o termo «chao» pode designar unha área moi ampla e, relativamente, diversa. Nunha das primeiras cartografías de Galicia, elaborada a finais do século XVI polo freire Fernando Oxea, o termo «Chao de Amoeyro» aparece referido con moita claridade ás dúas ribeiras do Barbantiño (Figura 2). O dato non é baladí tendo en conta que o autor do mapa era orixinario da propia cidade de Ourense (Cabano 1998: 203). A perspectiva popular contemporánea é un tanto diferente: unha vella revista cultural da zona, Bisbarra, consideraba que a súa comarca abarcaba Amoeiro, A Peroxa, Cea, Coles, Piñor e Vilamarín, estendéndose polo tanto máis ben cara ó leste e norte e non tanto cara ó poñente. O mesmo sucede cando observamos a extensión dos arciprestádegos eclesiásticos. Otero Pedraio, pola súa parte, define os «chaos» dun xeito bastante restritivo, porque a súa perspectiva está expresamente enfocada á súa parroquia, Trasalba. Aínda así, no artigo antes citado aporta algunhas claves ben interesantes: «o nome de chao pódese apricar n-un senso xerál ó conxunto das terras que temos considerado dend'a aba das serras ôs vals, mais propiamente dase ôs d'Amoeiro, comprendendo a mór porción d'ista parroquia, a de Fontefría, e parte de Parada d'Amoeiro. Palmés, Castro, Beiro (bocarribeiras do

\footnotetext{
${ }^{7}$ pese a todo, hai outros argumentos que tenden a, a lo menos, matizar as propostas de Calo, como é a indubidable documentación de elementos plásticos en contextos claramente prerromanos, por exemplo no castro de A Forca (Carballo 1996).
} 

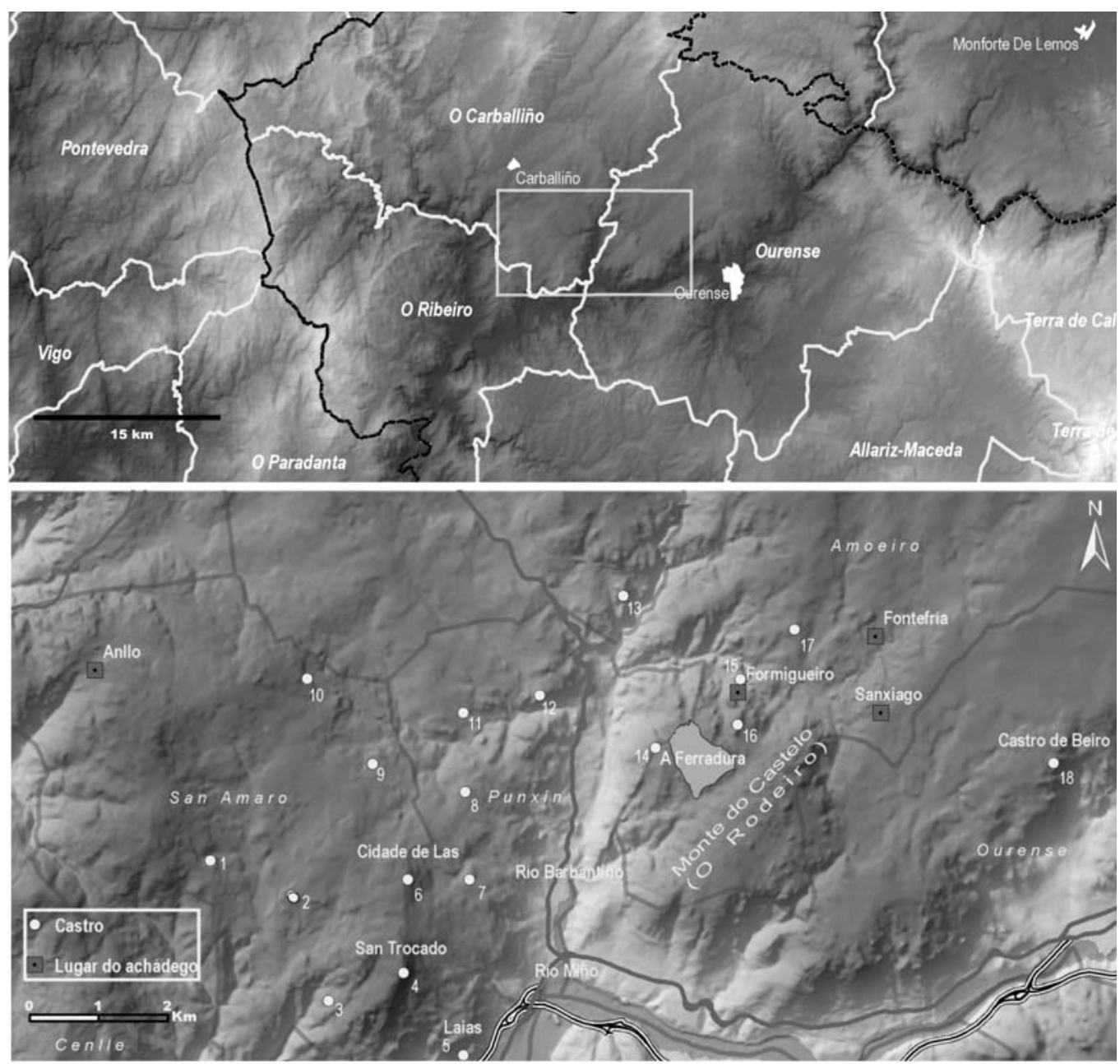

Figura 1. Os Chaos de Amoeiro. Castros: 1, Beariz; 2, Loucía; 3, Xinzo; 4, San Trocado; 5, As Laias; 6, San Cibrán das Lás; 7; Ourantes; 8, Freás; 9, Salamonde;10, As Quintas; 11, Vilela; 12, Vilamoure; 13, Santa Mariña; 14, A Zarra; 15, O Formigueiro; 16, Coto do Castro (Marmán); 17, A Poboanza; 18, Castro de Beiro (San Andrés).

Miño), Parada, Vilela, Vilamoure (bocarribeiras do Barbantiño), Ourantes, teñen carauteres semellantes ôs de Trasalba, soilo qu'en moito menor escala. (...) Beiro e sobre todo Amoeiro chegan á forma mais compreta de chao» (Otero 1927-8; n. ${ }^{\circ} 46$ : 3). Ademais dos «chaos» por excelencia, os de Amoeiro, existen tamén outras comarcas históricas nas chairas noroccidentais da provincia de Ourense, como a 
denominada «terra de Maside». As comarcas «naturais», por tanto, non son as mesmas segundo a fonte que consideremos. Supoñemos que é unha complexa cuestión de percepción da paisaxe e organización territorial, variable ó longo do tempo e a medida que se transforman as lindes administrativas.

Neste texto nos referiremos baixo a denominación de os Chaos de Amoeiro ao espazo situado na bacía media do Miño, xusto despois de que o río atravese a cidade de Ourense, coma dous penicháns localizados a ámbalas dúas beiras do río Barbantiño no seu derradeiro curso e inmediatamente antes de desembocar no Miño. A súa configuración administrativa comporíase fundamentalmente dos concellos de Amoeiro, Maside, San Amaro, Punxín e parte de Ourense. A súa poboación é moi reducida, mostra do despoboamento característico dalgunhas zonas da provincia de Ourense. É ademais rechamante o escaso impacto que unha poboación tan próxima coma a de Ourense tivo nos Chaos ata o de agora. O certo é que, debido a estas e outras razóns, atopamos nos Chaos unha fosilización da paisaxe rural tradicional galega que, quizais, non é sinxelo atopar noutras rexións. A escasa incidencia do fenómeno industrial e urbano nos Chaos de Amoeiro pódese entender en boa parte atendendo ás súas características fisiográficas. Estes espazos caracterízanse pola súa inaccesibilidade dende o sur, onde atopamos ladeiras escarpadas que rematan nos ríos Barbantiño e Miño. Iso explica que as principais arterias de comunicación, que conflúen ó sur, no centro urbano ourensán, arrodean os Chaos. En palabras de Otero Pedraio: «una de las causas de tal estancamiento proviene del siglo pasado y radica en el desvío del camino de Orense a Santiago que, al no cruzar O Chao, canalizó grandes actividades hacia otros rumbos» (Otero 1974: 62). Pese a este rasgo contemporáneo, e ó mesmo tempo, a zona atópase inserida nunha rede de camiños moi significativa ó longo da historia, que veremos en detalle máis adiante, e que explica a riqueza do seu patrimonio histórico. Por exemplo, a confluencia do Barbantiño co Miño é un dos eixes fundamentais da comunicación fluvial nesta provincia: a barca de Barbantes está documentada dende a lo menos o século $\mathrm{X}$ (Gallego Domínguez 1999: 108-112).

O poboamento dos Chaos ten, polo tanto, un carácter rural que entra dentro do que se pode definir tipicamente coma «tradicional», mais iso non significa que esteamos a plantexar a invariabilidade económica e social dos Chaos como paisaxe campesiño. De feito, os Chaos non foron liberados dos procesos de abandono do rural. É moi evidente o retroceso das terras roturadas e o fenómeno da emigración á cidade nas últimas décadas. Na actualidade, o monte e a repoboación forestal van gañándolle a partida ás terras de cultivo e prado. Nembargantes, o impacto medioambiental segue sendo moderado, aínda que as obras dos trazados do Tren de Alta Velocidade e a autopista Santiago-Ourense poderían nun futuro inmediato alterar 


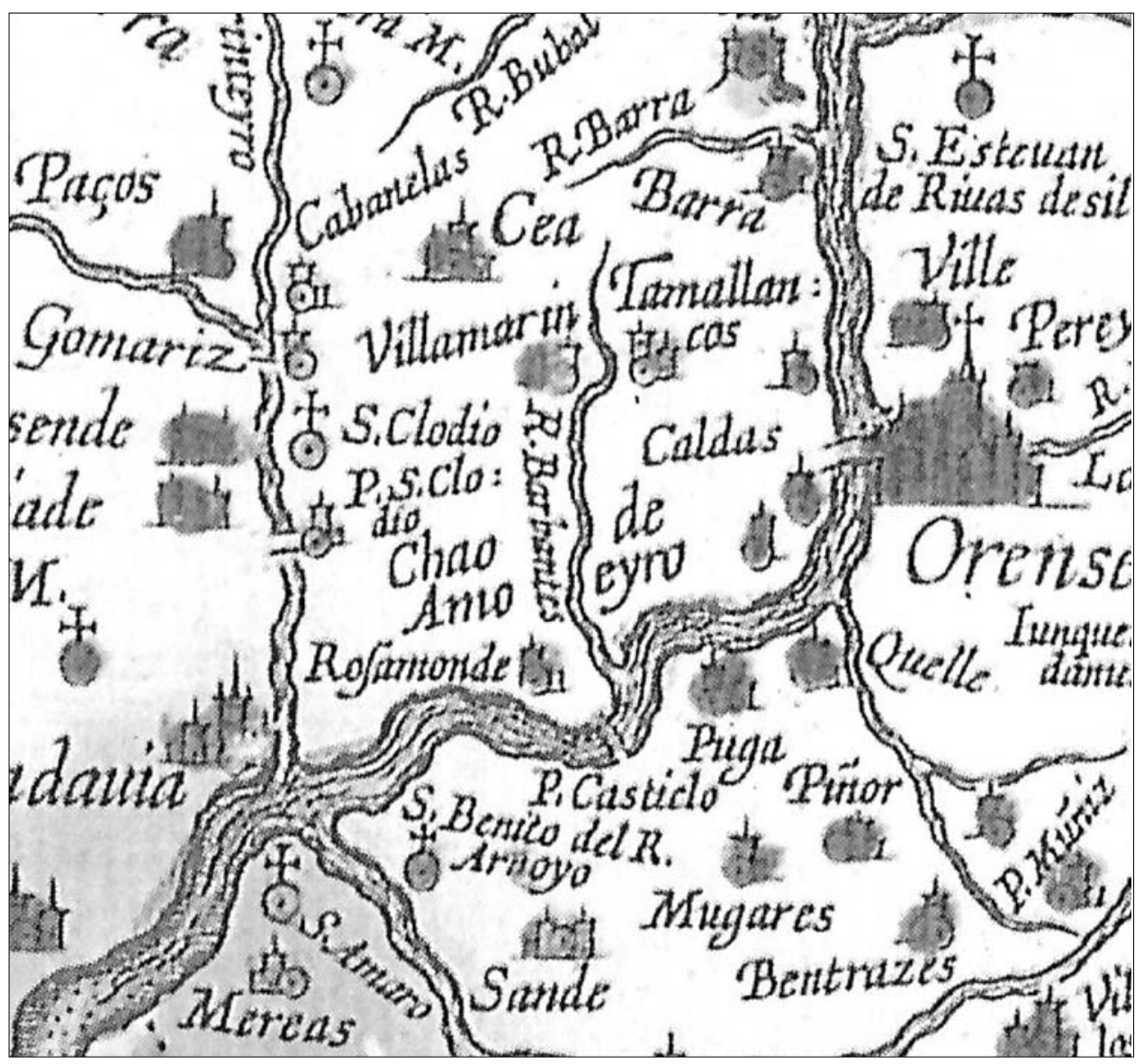

Figura 2. Os Chaos de Amoeiro nun mapa de finais do século XVI.

este equilibrio. De momento, a zona desfruta dunha especial conservación do patrimonio natural en virtude da súa economía campesiña.

En definitiva, estamos diante dunha paisaxe rural do interior galego, caracterizada por un poboamento concentrado en pequenos núcleos, onde a arquitectura en pedra pervivíu ata os nosos días e a organización do territorio en base a unha economía campesiña aínda pode ser recoñecida. 


\section{OS CHAOS DE AMOEIRO COMA PALEOPAISAXE ${ }^{8}$ : CARACTERIZACIÓN ARQUEOLÓXICA}

Como sucede frecuentemente nos concellos da provincia de Ourense, é difícil establecer un catálogo arqueolóxico exhaustivo para Amoeiro e os seus arredores. As planificacións de ordenación urbanística da zona destacan pola súa antigüidade ou inexistencia. A ausencia dun sistema de información do patrimonio de consulta pública non fai máis que complicar a cuestión. Pero o certo é que o entorno dos Chaos de Amoeiro aparece con relativa frecuencia na bibliografía arqueolóxica, por diversas razóns. Examinaremos brevemente as máis importantes.

O castro de San Cibrán das Lás, a chamada popularmente «cidade de Antioquía» (e mesmo «os muros dos arqueólogos», como nos dixeron algunha vez), é sen dúbida o xacemento arqueolóxico máis coñecido da rexión e un dos referentes da Idade do Ferro no noroeste peninsular, ata tal punto que a Xunta de Galicia elixiuno como eixo artellador da presentación pública do poboamento castrexo galego a través dun, aínda incompleto, «parque arqueolóxico da cultura castrexa» (Infante Roura et al. 2004). O feito de ter sido escavado dende antigo, restaurado recentemente e aínda novamente escavadas algunhas das zonas que quedaban virxes (a ladeira este) aporta un enorme interese científico. É obvio que este enorme xacemento (en torno ás $10 \mathrm{Ha}$ ) só pode ser analizado nun contexto moi amplo, tanto a nivel local como rexional. O primeiro elo nesa contextualización ven dado polo coñecemento doutros asentamentos no entorno inmediato, entre os que destaca o castro de Laias, escavado en ampla extensión antes do paso das obras da autovía Vigo-Ourense polo mesmo equipo que ten levado a cabo os recentes traballos en San Cibrán, e que ten fornecido unha boa cantidade de documentación arqueolóxica, coñecida xa en parte (Álvarez e López 2000). Lembraremos tamén a proximidade do xacemento de San Trocado, situado entre ambos, cuxa importancia etnográfica é fundamental para entender a territorialidade histórica da zona $^{9}$ e que tamén foi obxecto, hai algún tempo, de traballos de sondaxe (Chamoso 1953, 19545). Como dixemos, o interese pola rexión ven de moi antigo, das vellas intervencións de Chamoso Lamas no debatido xacemento de Barbantes (Chamoso 1954-5), do párrafo de Hidacio que fala do «municipio Lais» (López Cuevillas 1956) e da

${ }^{8}$ Paleopaisaxe é o título dun pequeno ensaio literario escrito en galego, en 1954, por F. López Cuevillas no que, en ton divulgativo, resume a súa visión da paisaxe da Idade do Ferro en Galicia (recollido en Otero Pedrayo 1980: 117-125).

${ }^{9}$ Cada 15 de Maio o castro do san Trocado ou Torcuato reúne ás parroquias do seu entorno baixo a presidencia do párroco de San Cibrán das Lás para proceder a unha moi simbólica benzón das terras circundantes. 
incógnita sobre a situación do lugar de «Aquas Laias» citado por Ptolomeo (Bejarano 1987: 89, 192). Por todas estas razóns a triloxía de castros San Cibrán das Lás / San Trocado / Laias segue a ser unha importante cuestión para a arqueoloxía da Idade do Ferro e da época indíxeno-romana en Galicia. Tentaremos revisar polo miúdo algunhas das principais cuestións.

O tamaño e monumentalidade de San Cibrán das Lás leva inevitablemente a pensar nun castro tipo oppidum con funcións que irían máis aló da produción e reprodución dunha comunidade local, hipótese xeralmente manexada para caracterizar aos asentamentos castrexos. Ademais deses dous factores, a estrutura do asentamento, que se podería definir como proto-urbana, e maila plástica da cultura material permiten establecer analoxías entre Lás e outros oppida do noroeste desenvolvidos a partir das últimas centurias da segunda Idade do Ferro e, máis concretamente, nun momento de apoxeo preto do cambio de era (González Ruibal 2003: 267-286). De feito, a estruturación política do territorio a partir de grandes poboados é un proceso común en toda Europa central e occidental. Un dos argumentos esgrimidos para reafirmar a proxección territorial destes grandes castros foi a equidistancia entre eles ou, polo menos, unha supremacía clara do seu tamaño en relación cos poboados situados nunha hipotética área de influencia.

A visibilidade total do xacemento de San Cibrán ${ }^{10}$ abarca de feito boa parte dos penicháns situados a ámbalas dúas beiras do Barbantiño e, de forma máis descontinua, é apreciable ao longo de toda a depresión noroccidental da provincia de Ourense. Debemos sinalar tamén que, de forma máis puntual, dende o oppidum tense acceso visual a algunhas zonas altas situadas máis aló dos límites sinalados con anterioridade, tales como algunhas rexións da meseta e serra oriental e meridional de Ourense e as serras sudorientais de Lugo. O que queremos transmitir é que a cunca visual do xacemento podería estar relacionada, dalgún xeito, coa súa proxección territorial.

En poucas palabras, a pregunta que nos plantexamos é se unha concentración de achados de plástica castrexa como os que de seguido se presentan podería explicarse pola existencia na zona dun oppidum coma Lás, na liña das propostas que defenden un apoxeo da plástica en pedra indíxena entre finais do s. II a.C. e finais do S. I a.C., coincidindo co desenvolvemento destes grandes castros (p.e. González Ruibal 2003). Un dos grandes debates sobre protohistoria castrexa dos últimos tempos refírese ó sentido da tradición plástica dos pobos prerromanos, así como ós factores sociais que participan na súa elaboración. Obviamente, neste texto non

\footnotetext{
${ }^{10}$ Calculada en consonancia coa metodoloxía empregada por C. Parcero e P. Fábrega noutros traballos: Parcero 2001; Fábrega 2004; Fábrega 2005; Parcero e Fábrega 2006.
} 
pretendemos abordar en profundidade todas estas cuestións senón máis ben aportar elementos para reconsiderar o «estado da cuestión» tendo en conta os novos achados que presentamos e o seu estudo contextual e comparativo. Desexaríamos, sobre todo, propoñer nova materia de debate.

As recentes intervencións no castro de San Cibrán teñen aportado pezas fundamentais para a interpretación do xacemento, notablemente as dúas inscricións atopadas na croa, que se engaden á inscrición do IOVI e á famosa ara adicada a Bandua Lansbricae (Álvarez et al. 2004). A que reza SADV VLADV é importante porque introduce un epígrafe posiblemente en lingua indíxena aínda non descifrado, renovando as hipóteses sobre o carácter «romano» do asentamento. A de NABIA ABIONE, quizais a máis interesante para este artigo, introduce implicacións comarcais de importancia, dado que o termo Abione semella ter algunha relación etimolóxica co actual topónimo do río Avia. Con datos coma este, é tempo de comezar a plantexar hipóteses sobre supralocalidade castrexa: os Chaos de Amoeiro poderían ser unha zona especialmente apta para este propósito, sobre todo ante a evidencia de castros tan conspicuos como San Facundo, A Martiñá, a Santádega e ante certas referencias do folklore popular, significativas dende o punto de vista territorial: «o Castro Morgadán ten vintecinco á súa man, / soio o da Madanela lle da pola barbadela». O epígrafe atopado na croa de San Cibrán suxire interesantes hipóteses sobre territorialidade e supralocalidade na zona do río Avia (castros do entorno da Pena Corneira, castro de San Vicenzo de Avión, etc; remitimos ó excelente traballo de García Álvarez (1953), destacando por exemplo o «castro Bou Bou» ou o «castro da Man da Moura», plenos de referencias medievais.

É necesario que a arqueoloxía da Idade do Ferro en Galicia saia dos recintos fortificados para pasar a explicar o conxunto do territorio. A maiores, a existencia do complexo de gravados de A Ferradura, no concello de Amoeiro, complica aínda máis a cuestión por introducir unha compoñente non habitacional na zona, para cuia significación histórica se teñen aportado suxerencias novidosas no eido da historia das relixións, da arqueotopografía e, quizais máis hipoteticamente, no eido da arqueoastronomía (García e Santos 2004a). Non pretendemos explicar polo miúdo a «hipótese Ferradura» (remitimos para iso á bibliografía ó respecto), pero si estamos obrigados a sintetizala brevemente.

$\mathrm{A}$ «chan» $\mathrm{e}$ «pedra» da Ferradura, pois ambas reciben o mesmo nome, son coñecidas na bibliografía arqueolóxica dende a lo menos 1998 (Amado et al. 1998). Dende entón García Quintela e Santos Estévez teñen dado a coñecer varias veces as súas substanciosas hipóteses sobre o lugar (García e Santos 2000, 2004a, 2004b; Santos e García 2000; Santos e Seoane 2004; García Quintela 2006). Nestes artigos falan, en resume, dunha chaira en altura desprovista de poboación histórica e 
prehistórica no seu amplo sector central, onde os únicos xacementos arqueolóxicos son gravados rupestres, sinxelos e moi abundantes na periferia do lugar e máis complexos nun ou varios lugares centrais. Tratase de petroglifos diferentes ós tradicionalmente datados na Idade do Bronce, que, seguindo esta hipótese, poderían delimitar e marcar lugares de orde ritual: a súa investigación permitiulles identificar varios exemplos, entre os cales a Ferradura é quizais o principal. A súa proposta defende que os petroglifos asociados á chan da Ferradura, e sobre todo á pedra homónima da Ferradura, son testemuña dunha serie de posibles rituais de investidura, que eles sitúan na Idade do Ferro, dentro dun marco cultural de tradición céltica i en directa relación co xacemento de San Cibrán das Lás. É frecuente no folklore galego, e mesmo europeo, que dous xacementos ${ }^{11}$ aparezan ligados porque unha personaxe mitolóxica (san Patricio, o apóstolo Santiago, Roldán ou un mouro calquera) salta co seu cabalo deixando as pegadas das ferraduras nunha pedra con petroglifos. En certo modo, estes autores establecen un vencello entre petroglifos de pés humanos, lendas sobre ferraduras e actividades de tipo ritual, nexo sustentado ademais con numerosos paralelos históricos e mesmo etnográficos ${ }^{12}$. $\mathrm{O}$ máis importante é que a súa hipótese permite plantexar a existencia dunha relación histórica ou funcional entre dous xacementos de época castrexa ${ }^{13}$. A colación dos traballos de García Quintela e Santos Estévez podemos facer referencia ó podomorfo orientado directamente á sauna con forno de Briteiros (Figura 3), xa citado noutros lugares (González Ruibal 2003: 454) e tamén os propios podomorfos do santuario de Panoias. O certo é que o convento bracarense é unha auténtica mina de «evidencias atípicas»: quen sabe se non acabaremos identificando como «santuarios» boa parte daqueles «lagares dos mouros» dos que falaba Mario Cardozo, sobre todo á vista de xacementos tan destacados como o Castelo do Mau Vizinho ou o das Laias / Barbantes, antes citado ${ }^{14}$. Pensamos, por exemplo, nas múltiples penas con pías que López Cuevillas e Xaquín Lorenzo (1952) atopan no sur de Galicia, tamén

\footnotetext{
${ }^{11} \mathrm{Na}$ hipótese de García Quintela e Santos Estévez serían o «asentamento» e o mailo «santuario».

${ }^{12} \mathrm{Na}$ bibliografía arqueolóxica tradicional xa existía algún apunte que suxería as posibilidades da investigación neste eido: por exemplo, un artigo de Fermín Bouza Brey (1938) sobre petroglifos de ferraduras, onde constataba a abundancia deste motivo na Galicia interior e a relativa ausencia na franxa costeira, na que se atopan os petroglifos prehistóricos máis característicos e coñecidos.

${ }^{13}$ Había outros factores para propoñer a existencia deste «santuario» e maila relación entre xacementos, dado que se traballaba no marco da proposta «predictiva» de espazos sagrados en arqueoloxía prantexada en Santos et al. (1997). Entre os factores a ter en conta destacaba, por exemplo, a existencia dunha fronteira «antinatural» entre Punxín e Amoeiro (o límite do primeiro concello sobrepasa o encaixado val do Barbantiño). Véxase ademais a Figura 2.

${ }^{14}$ Para un repaso xeral a este tipo de xacementos, os denominados «santuarios rupestres», véxase González Ruibal 2003: 462-9.
} 


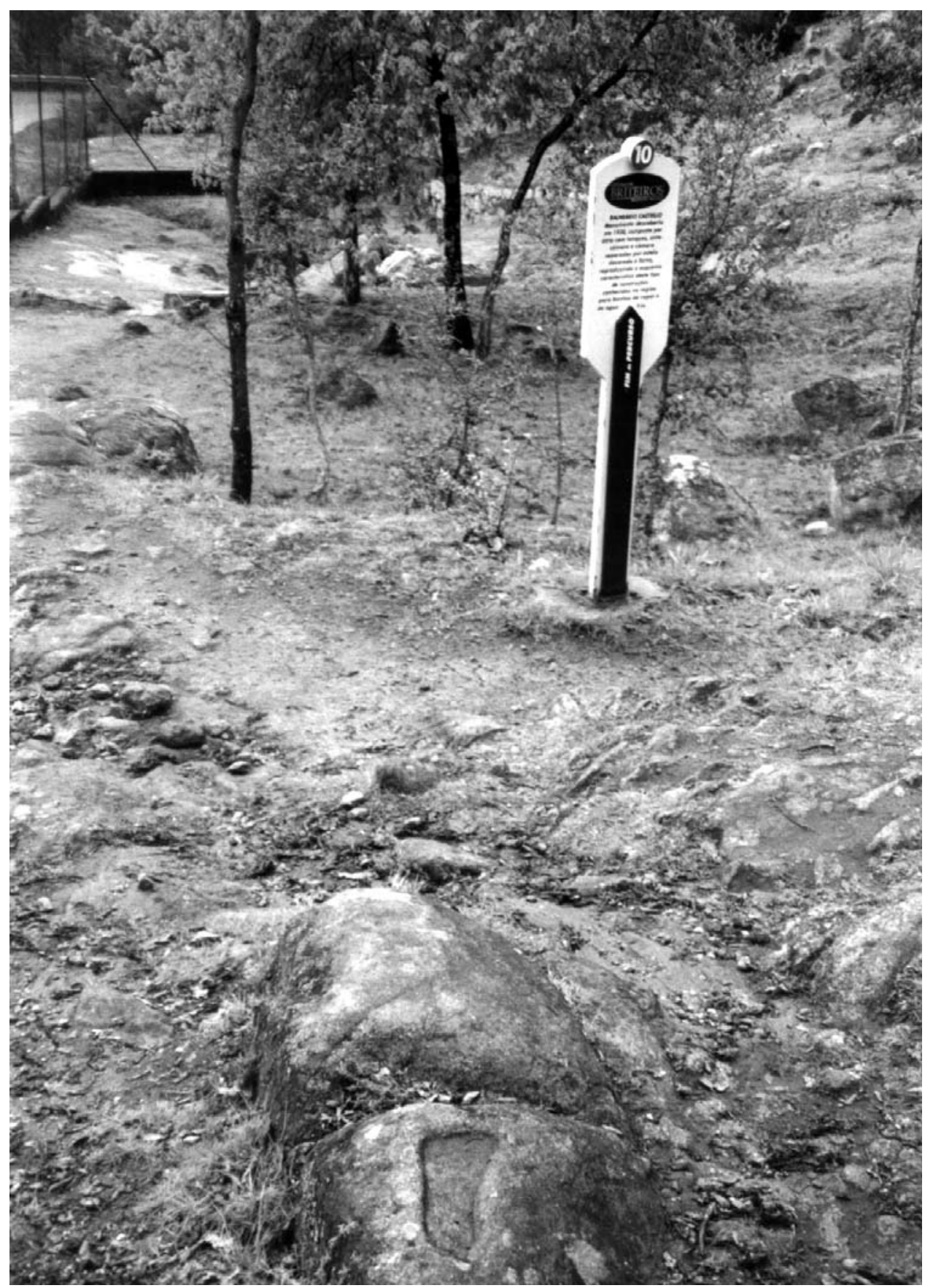

Figura 3. Un podomorfo «apuntando» á pedra formosa do castro de Briteiros. 
na rexión de San Cibrán das Lás, que poderían constituír un último epígono destes xacementos polo norte.

En consecuencia, cremos que os traballos de Santos e García sobre a posible adscrición cultural da Ferradura á Idade do Ferro concretan aínda máis a importancia da zona como «rexión de referencia» política e económica, pero tamén simbólica, para este período.

\section{NOVOS ACHADOS: NA BUSCA DUN CONTEXTO}

No contexto de traballos de control de impacto arqueolóxico de obras públicas, en concreto, coa construción da canalización do gas na provincia de Ourense, realizáronse determinadas actuacións nos Chaos de Amoeiro, sendo localizados algúns xacementos inéditos (Amado et al. 1998). Entre eles cabe destacar Os Castros de Zarra, Vilamoure e Coto do Castelo, así coma o xacemento tardorromano de As Pereiras (Aboal e Cobas 1999) e a descuberta dos petroglifos da Ferradura, que deu lugar ó seu estudio sistemático.

\subsection{A Ferradura}

Con ocasión daqueles traballos, Manuel Santos Estévez elabora unha hipótese sobre os petroglifos, entón inéditos, da chan da Ferradura, na parroquia de Trasalba (Amoeiro), logo apoiada e completada pola comparación histórica elaborada por Marco V. García Quintela. Os autores deste artigo, coma colaboradores e compañeiros dos anteriores, tivemos a oportunidade de discutir as súas hipóteses e a posibilidade de continuar con novas buscas. En concreto, nas nosas prospeccións témonos interesado polo folklore asociado á chan da Ferradura.

Como xa constatara Manuel Santos (comunicación personal), a xente aparentemente descoñecía os petroglifos asociados á chan. O nome mesmo de «Ferradura» non era demasiado común: de feito, Otero Pedraio en ningún caso emprega a palabra «Ferradura» nin «chan da Ferradura»: para esa zona emprega o nome xeral de Faracho, aldea hoxe abandonada nas abas da chaira que caen contra Punxín. Pero os tempos cambiaron e os propios habitantes de Amoeiro comezan a chamar á pedra «pedra da investidura». Pese a todo, si puidemos atopar algún indicios folclóricos de interese. En Albeiros un home de idade avanzada dixo, en referencia ás lendas sobre ferraduras, que a pedra tiña unha «man» gravada. Hai tamén unha interesante lenda recollida por Otero:

«En 1923 murió en Cima de Vila de Trasalba (Orense) el viejo señor Ignacio, enjuto y serio de ochenta y cinco años; de joven había sido gran tunante y luchador 
con mozas. Andaba de noche, lo que, según decía, de viejo «non e bo». Una noche muy clara encontró al lado de la fonte vella, que aún existe, una mujer muy vestida y ceñida de hermoso tipo. Quiso luchar con ella, y luchó hasta cansarse, aunque era muy fuerte, y sin conseguir ni soltarle un botón del ajustado justillo. De pronto tuvo miedo: pensó ser aparición y la abandonó. Ella llevaba calzado muy claveteado, que hacía rechinar en la lucha la arena seca del camino. En cuanto amaneció, volvió al lugar; sólo estaban las huellas de los zuecos de él; de ella nada, cuando debían haberse impreso. Y quedó confirmado en su idea y temor» (Otero Pedrayo 1976: 408).

Trátase dunha referencia un tanto velada ós pés (ou gravados de pés) dunha «moura» ou aparición sobrenatural, referencia estruturalmente invertida nesta ocasión: pese a estar «claveteados» como as ferraduras das bestas, os pés da aparición desaparecen, en realidade, pero segue a ser fundamental a idea do pé e da súa imaxe no chan. A fonte vella aínda existe hoxe, nas proximidades da igrexa parroquial, malamente disimulada entre un triste montón de cemento. Sobre esta zona central da parroquia de Trasalba, Otero sinalaba o seu «prestixio particolar no folklore de bruxas e estadeas, quizais pol-a presenza do adral ou cemiterio e da eirexa, quizais gardando a lonxana lembranza d'un castro ou logar primitivamente sagrado. É sabido como as eirexas foron postas no logar dos antigos santuarios (Otero 1927-8; n. ${ }^{\circ}$ 52: 70).

No eido máis estritamente arqueolóxico puidemos confirmar o carácter castrexo do asentamento do «Coto do Castro», ou coto de Marrán ou Marmán, como aparece na cartografía oficial e como o denomina o propio Otero Pedraio. Alí atopamos, tras un recente incendio, estruturas arquitectónicas máis ou menos visibles, tégulas case enteiras e abundante cerámica, algunha mesmo decorada con decoración indíxena. Por desgraza, o estado dos petroglifos documentados por Manuel Santos Estévez estaba enormemente deteriorado pola acción do lume.

Asemade, visitando o castro da Zarra puidemos documentar numerosos petroglifos. A meirande parte deles semellan asociados ó caracter de límite administrativo deste coto, sobresaíndo tamén un bo número de «coviñas» de cronoloxía indeterminada. Pero existe a lo menos unha interesantísima excepción: o día 21 de Xuño de 2003, nunha visita realizada con motivo do solsticio de verán, atopamos no castro da Zarra un peculiar abrigo cun petroglifo (Figura 4) moi semellante, técnica e tipoloxicamente, ó petroglifo do abrigo do Raposo, xa sinalado por Santos Estévez e García Quintela. O Raposo constitúe, de feito, na hipótese destes dous autores, o segundo «petroglifo central» da chan da Ferradura. Consideramos que este achado dalgún xeito ven a completar as hipóteses plantexadas para o petroglifo do abrigo do Raposo, que deixa de ser excepcional e único para poder ser contrastado. 

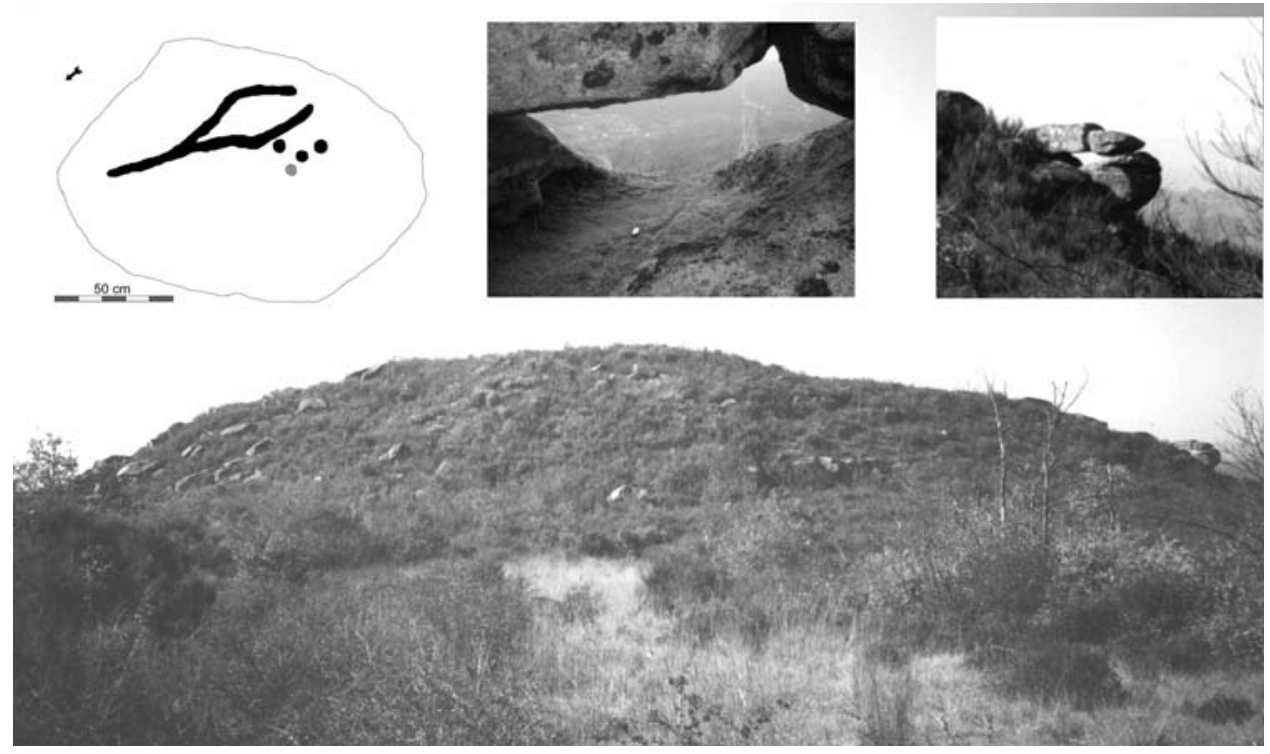

Figura 4. O castro, abrigo e petroglifo da Zarra, na chan da Ferradura, dende o leste. Calco de Yolanda Seoane e Manuel Santos.

\subsection{O Formigueiro}

Paralelamente ao desenvolvemento dos traballos aludidos na chaira da Ferradura, a nosa compañeira Isabel Cobas tivo coñecemento da existencia dunha lousa decorada na aldea veciña do Formigueiro. En colaboración cos veciños deste lugar, desenvolveu un amplo traballo de documentación i elaborou unha posible reconstrución da grande pedra decorada da súa capela tendo en conta outros fragmentos dispersos polas casas dos arredores. Este traballo, rematado en Xuño do 2001, permaneceu inédito, pero del dá conta o debuxo da figura 5. Esta pedra aparecerá citada e fotografada por vez primeira para a bibliografía científica en Seara Carballo (2002), que ofrece detalles sobre o contexto da súa (re)descuberta e data a mesma no ano 1988. Posteriormente aparecerán outros traballos sobre o mesmo: unha pequena cita en Estévez 2002, onde se interpreta como proba da existencia dunha «sauna» ou «balneario» de tipo castrexo, e, sobre todo, Castro i Estévez (2003), onde aparecen tamén referencias e fotografías dos fragmentos da Fontefría e San Xiao, para pasar a continuación a debater o simbolismo indoeuropeo do cabalo ${ }^{15}$.

\footnotetext{
${ }^{15}$ Advertimos dun pequeno erro descritivo neste último traballo: o «sogueado lateral» que mencionan non se atopa na pedra do Formigueiro senón na do lavadoiro da Fontefría, da que logo falare-
} 
A pedra foi utilizada como mesa do altar da capela, descuberta ó facer unha recente restauración. Os habitantes do Formigueiro decidiron colocala na fachada da capela, a modo de «tímpano» ou similar. O santuario está adicado á Candelaria e a San Sebastián: unha grande pedra no lateral norte sinala o lugar no que se di que estaba soterrado San Sebastián. Seara Carballo (2002: 145) falaba no seu momento dun sepulcro escavado na rocha: semella que este foi atuado en tempos recentes, porque nalgún momento das nosas visitas puidemos escoitar a frase «está o burato... metemos cemento...». No interior da capela consérvanse importantes pezas de arte relixiosa popular en madeira.

O carácter castrexo da grande lousa parece firmemente contrastado, sobre todo polo motivo central. Tódolos autores citados fan referencia ós paralelos, documentados en Calo Lourido (1994: 179-81, 185-6, 216, 280, 290, 362, 365, etc. (véxase Figura 6, arriba). Este motivo é moi abundante en xacementos castrexos: o máis interesante é a súa repetida asociación con «pedras formosas» (é dicir, coas decoracións asociadas a monumentos con forno). Castro i Estévez (2003: 55) din que se trata dunha «sucesión de SS con punta de flechas (motivo similar a los llamados dragones pareados)», relacionándoa co «primeiro horizonte do arte laténico centroeuropeo». Pola súa parte, Blanco Freijeiro (1958) considera este motivo como unha serie de «palmetas de lira», motivo oriental con evidentes e abundantes derivacións peninsulares e relativamente frecuente na zona sur da cultura castrexa. As decoracións das pedras formosas de Briteiros e Sabroso, por exemplo, son liras encadeadas segundo este autor, con múltiples paralelos orientais entre os que destacan as espadas decoradas de La Osera (Ávila) ou Alcácer do Sal (Figura 6, abaixo). O mesmo autor considera que estes paralelos non se poden explicar por «xeneración espontánea». É interesante que tal motivo chegue ata a plástica castrexa, quizais adaptándose e reinterpretando motivos xa existentes: «la abundancia de liras en la Meseta indica que también aquí se conocía el motivo y que las gentes de estos castros lo utilizaban a menudo en sus decoraciones (...) En la arquitectura castreña el tema forma series verticales y horizontales (...) de liras encadenadas, como había sido frecuente y con formas muy similares en el arte etrusco de época arcaica (...) Ahora bien: aunque estos paralelos etruscos ayudan a comprender la significación de los temas castreños, no parece lógico pensar que hayan sido la fuente directa de esta decoración. Es mucho más natural explicarla como interpretación indígena de un motivo clásico que viene extendiéndose por toda la península desde el litoral mediterráneo, a partir probable-

mos (Castro i Estévez 2003: 53: «el releve de Formigueiros (...) tampoco parece haber formado parte de una pedra formosa pues tiene un sogueado en uno de los cantos que parece incompatible con esa función»). 

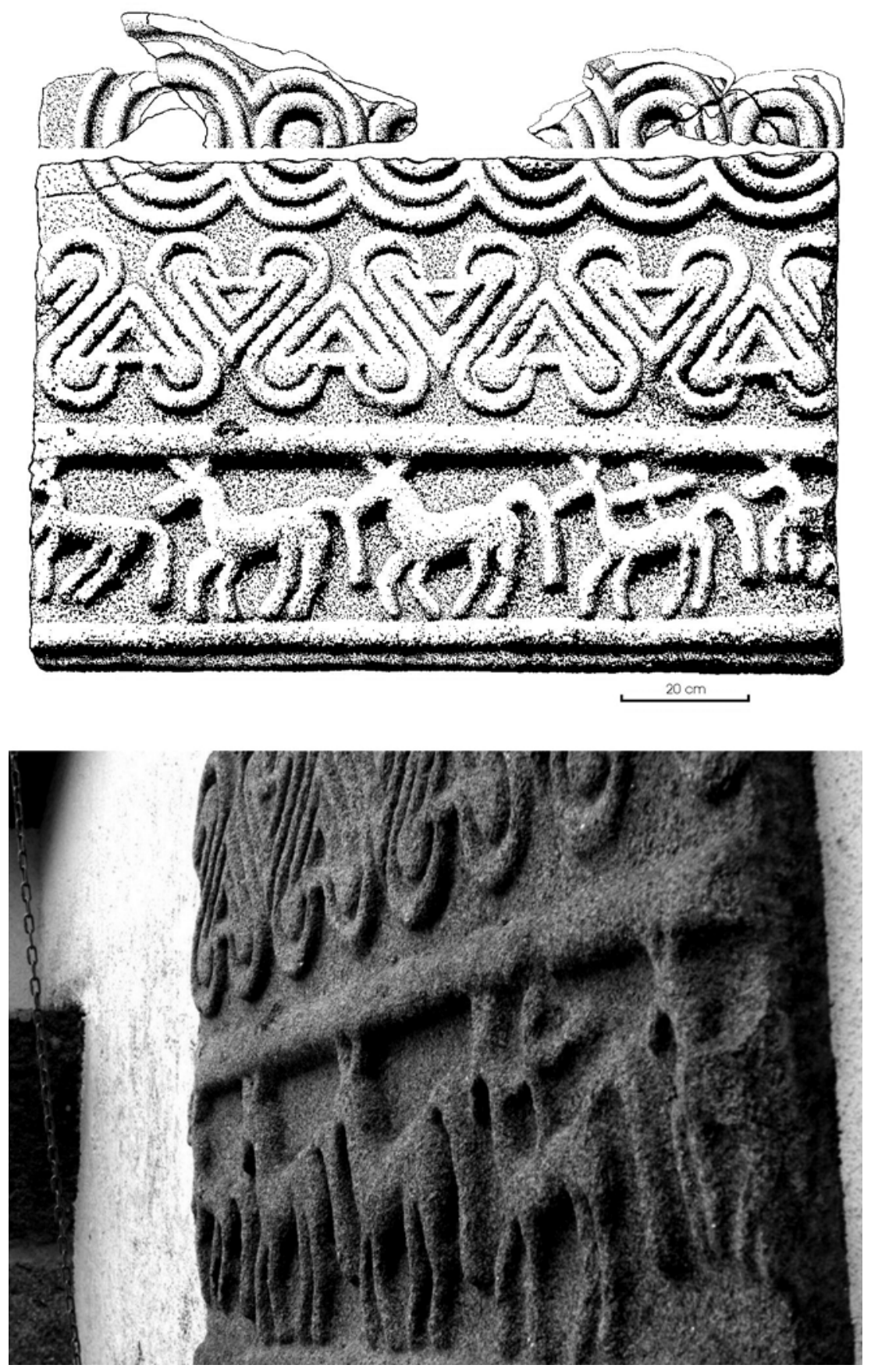

Figura 5. A grande pedra decorada da capela do Formigueiro. 


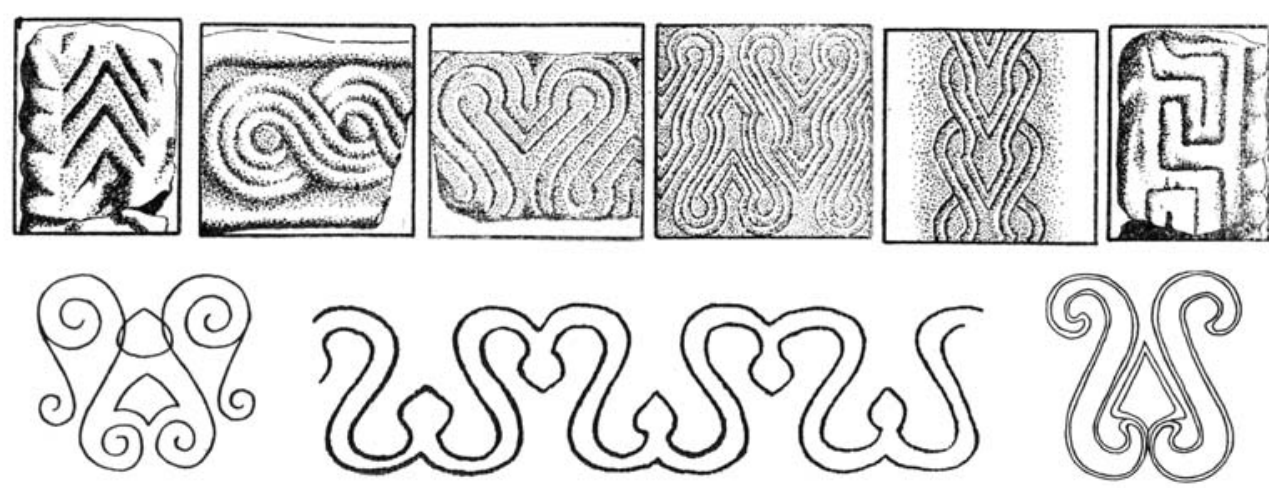

Figura 6. Arriba, algúns paralelos tipolóxicos das pezas presentadas (de esquerda a dereita, Cendufe, Rubiás, Sabroso, Vermoim, Briteiros, Cendufe; López e Lorenzo 1946: 56). Abaixo, algúns paralelos peninsulares e mediterráneos da «palmeta de lira» (de esquerda a dereita, La Osera, Chiusi, Alcácer do Sal; Blanco Freijeiro 1958).

mente del siglo $\mathrm{V}$, cuando todos los pueblos de Occidente reaccionan ante los motivos clásicos que llegan hasta ellos» (Blanco Freijeiro 1958: 196).

O máis probable é que o castelo do Formigueiro sexa a procedencia destas pezas (se ben non se pode descartar a posibilidade de que procedan doutros xacementos). Entre as hipóteses máis repetidas figura a que «imaxina», con certo atrevemento, que a situación da vila (medieval) do Formigueiro e o lugar que ocupa a propia capela podería corresponderse coa situación da sauna castrexa ou «pedra formosa» do poboado. Aínda que moi tentativa, non é unha hipótese completamente descabellada, dada a propia posición topográfica da aldea, a abundancia de pedras decoradas nas casas circundantes e a aparición de numerosos fragmentos cerámicos nas fincas que rodean as casas do lugar.

O xacemento medieval do castelo do Formigueiro é relativamente ben coñecido. Importante referente da comarca e coñecido primitivamente como castelo de Alba de Búbal (de onde derivaría o topónimo «Trasalba»), cabeza de xurisdición dos Chaos de Amoeiro e ubicado na parroquia de Trasalba, existe a lo menos dende o século XI. Derrocado polos irmandiños e reconstruído máis tarde, mantívose ata a idade moderna precisamente por ser cabeza de xurisdición ${ }^{16}$. Segundo a Gran

\footnotetext{
${ }^{16}$ Os reis católicos, tralos acontecementos dos irmandiños e das múltiples loitas nobiliares en Galicia, ordenaron derrocar tódalas fortalezas que non fosen cabeza de xurisdición, como medio de control do territorio. É significativo que esta fortaleza e antigo castro tivese esa posición xerárquica superior sobre as moitas do entorno, dado o seu encaixamento nun relativamente fondo e umbro val. A fortaleza do Formigueiro era poderosa precisamente por estar parcialmente oculta, destacando tamén o agreste da súa fortificación natural e a súa visibilidade selectiva sobre o val do Barbantiño, ó poñente.
} 

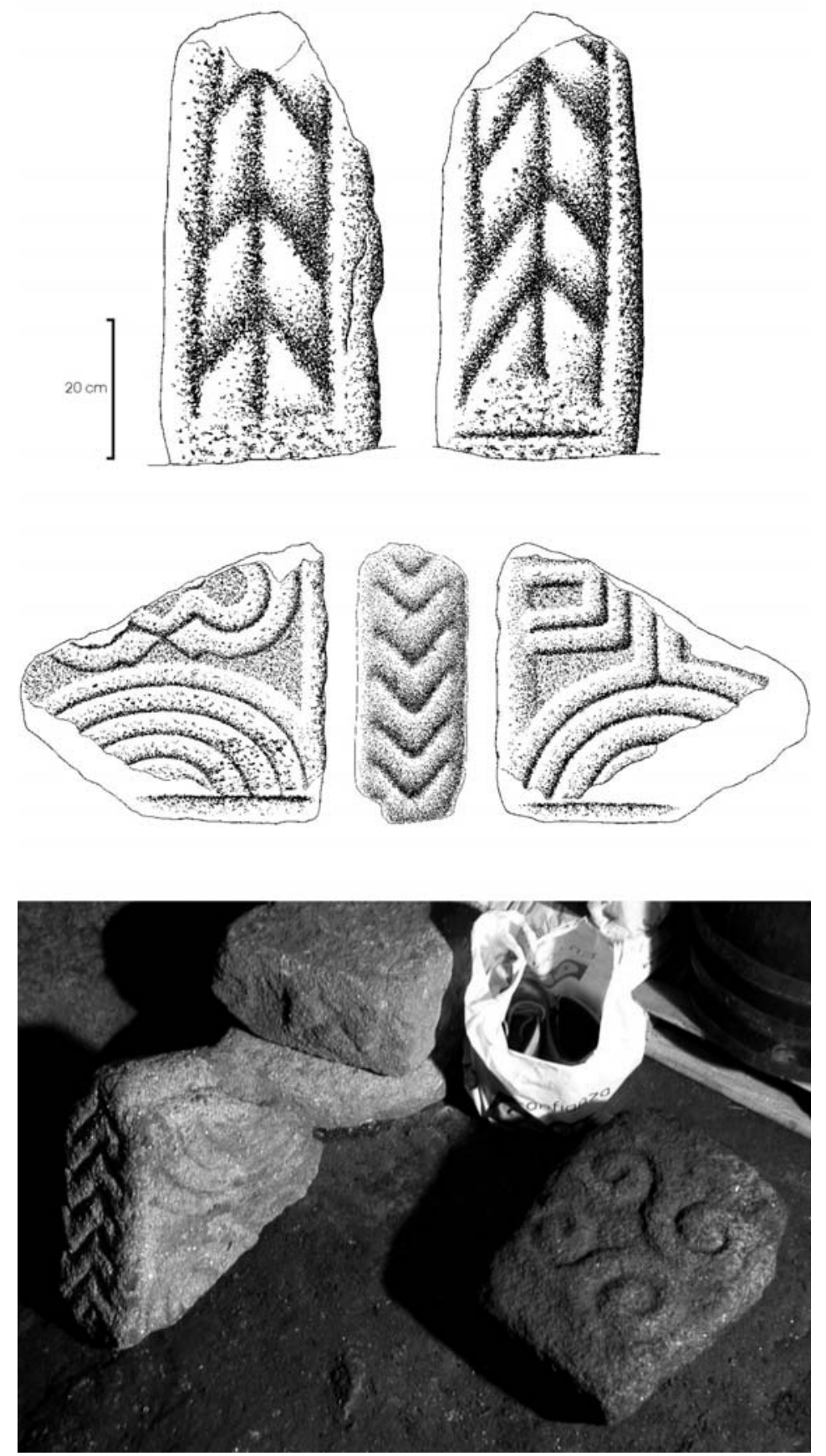

Figura 7. Varios fragmentos reutilizados no Formigueiro, case todos con decoración por varias das súas caras. 
Enciclopedia Gallega, en 1809 a xente dos Chaos salvou o seu gando da requisa dos franceses agochándose nos «subterráneos abovedados» do castelo. O texto, de autor non precisado, engade «en el presente han desaparecido hasta los caminos helicoidales de acceso, y sólo queda un pozo excavado en la ladera y unos derrumbes de mampostería». Tamén Otero (1927-8; n. ${ }^{\circ}$ 52: 69-70) fala deste castelo, da súa importancia na Idade Media e menciona especificamente o topónimo «castro» a el asociado, así como as lendas sobre «mouras» relacionadas co mesmo. O folklore do castro e castelo do Formigueiro ten, efectivamente, unha forte vida. «Tede coidado coas cobras» - avisábannos cando vían que nos dispoñiamos a subir. Tamén dicían que o lugar estaba «choco», que «nel, a auga non baixa senón que empapa», o que constitúe unha alusión ós restos que se conservan baixo terra.

Nas nosas visitas puidemos documentar varias terrazas, unha cabana circular, un profundo pozo de sección cadrada e tipoloxía medieval e un petroglifo tamén do mesmo período, no que aparece unha espada e outros signos non ben determinados. $\mathrm{Na}$ croa aparecen restos da base das edificacións e abundante tégula. No sector norte, moi abaixo da plataforma superior, indicáronnos a existencia dun topónimo «Pena Oubiña» asociado a lendas de animais mitolóxicos (corvos, cabras). Xunto a impresionantes derrubes, atopamos no lugar unha terraza, que podería delimitar o recinto exterior do castelo.

Co recoñecemento do lugar, e grazas á extraordinaria amabilidade da xente do Formigueiro, fomos coñecendo unha serie de fragmentos decorados reutilizados en vivendas privadas. Ofrecemos debuxos e fotografías dos máis significativos (figs. $7,8,9,10)$. O segundo en tamaño trala lousa principal (Figura 8) aparecía xa fotografado en Seara Carballo (2002) e fora tamén documentado pola nosa compañeira Isabel Cobas. Destacan ademais varios fragmentos con decoración por dúas das súas caras (por exemplo, Figura 7, arriba), así como un magnífico exemplo decorado por tres caras (Figura 7, centro, e 9). A súa feitura e conservación é excepcional en moitos casos. Apareceron tamén dúas columnas (unha delas ó lado da capela) e unha basa das mesmas, posiblemente de época medieval. No mesmo lenzo que esta basa de columna aparecía un reticulado (Figura 17). No interior desta parede a pedra foi lavada, ata tal punto que a documentación fotográfica non permite caracterizalos. Nembargantes, puidemos atopar de novo o reticulado (na mesma pedra pola cara oposta) e apenas dous brazos dun pequeno trisquel empotrado no muro. Tamén destaca o achado dun tetrasquel ou «lauburu», recoñecible pese á erosión (Figura 10, arriba á esquerda e abaixo). Aínda que algunha das pezas podería proceder de época medieval, o conxunto é bastante homoxéneo na tradición estilística protohistórica: como diciamos na introdución, remitimos á bibliografía especializada en plástica castrexa (López e Lorenzo 1946; Calo 1994) para contrastar os 

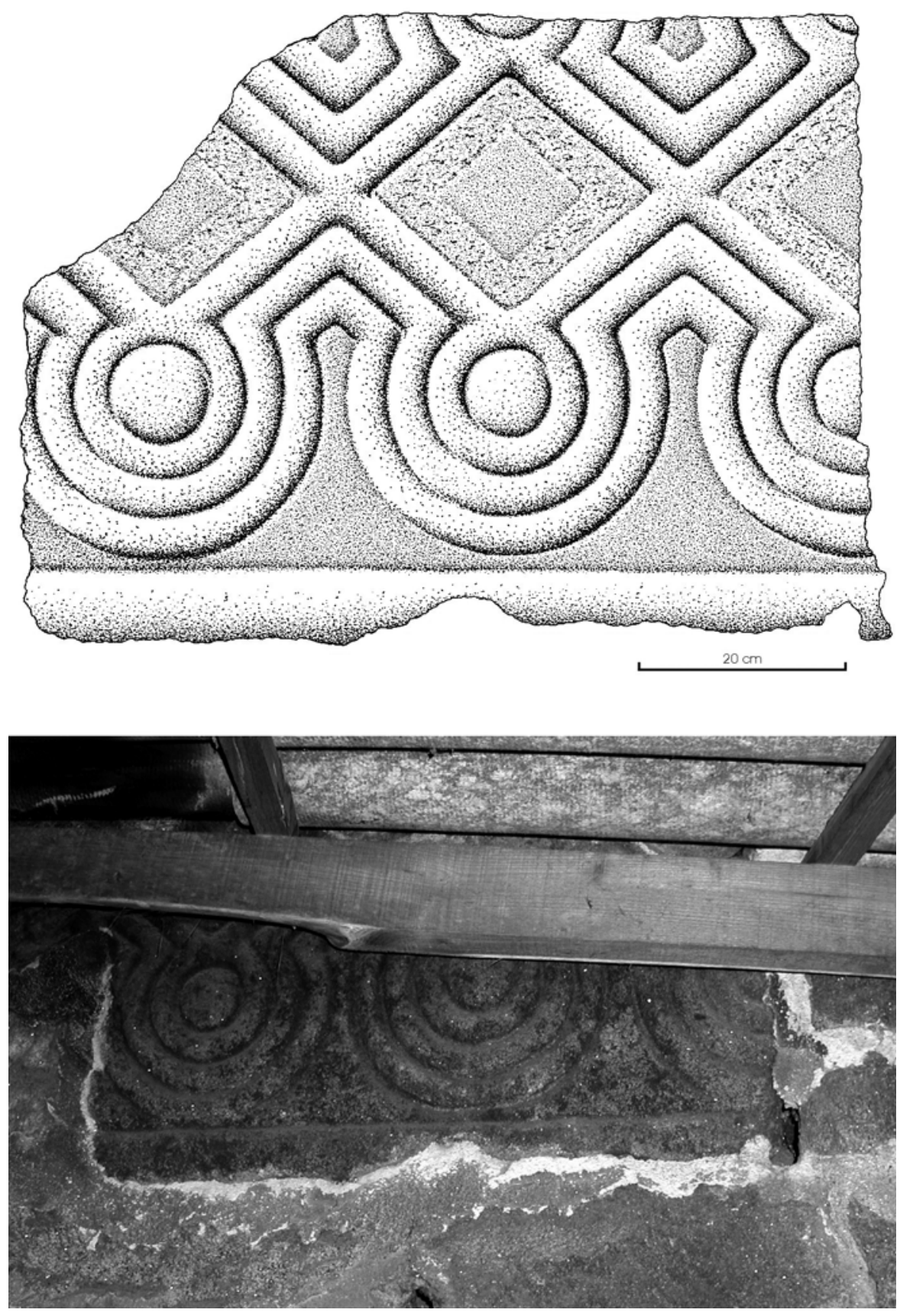

Figura 8. O fragmento máis grande do Formigueiro trala pedra da capela, un motivo de certa semellanza co exemplo da Fontefría. 


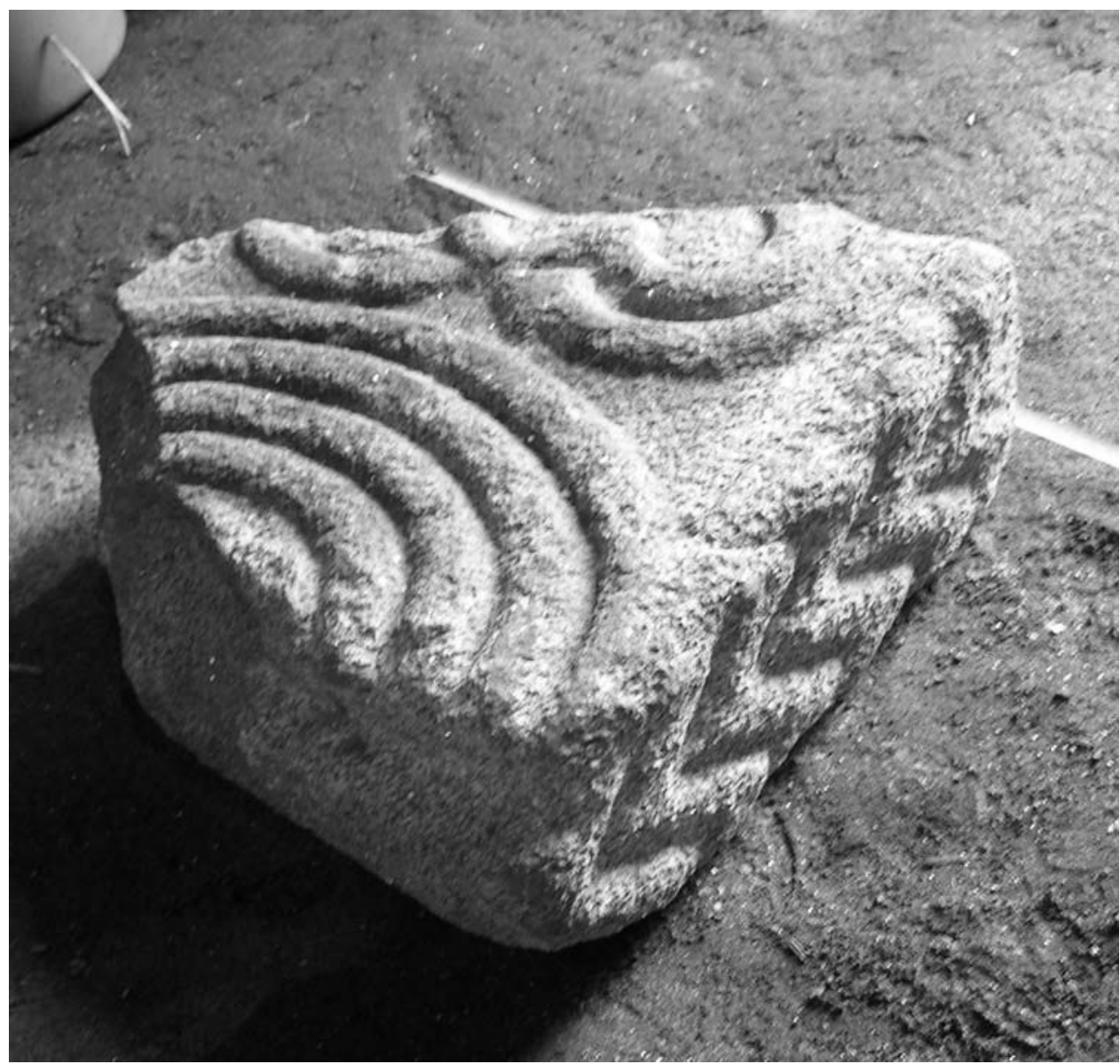

Figura 9. Magnífico exemplo decorado por tres das súas caras (Figura 7, centro).

paralelos. Tivemos coñecemento do último destes constantes achados o día 2 de Febreiro de 2006, mais supoñemos que o Formigueiro agocha aínda as mellores sorpresas.

\subsection{Santa Mariña da Fontefría e a capela de san Xiago}

Nun momento inicial das nosas exploracións, e trala publicación do artigo de Castro i Estévez (2003), achegámonos ata o lavadoiro de Santa Mariña da Fontefría no que se conserva outra pedra decorada (Figura 11). A calidade técnica do gra- 

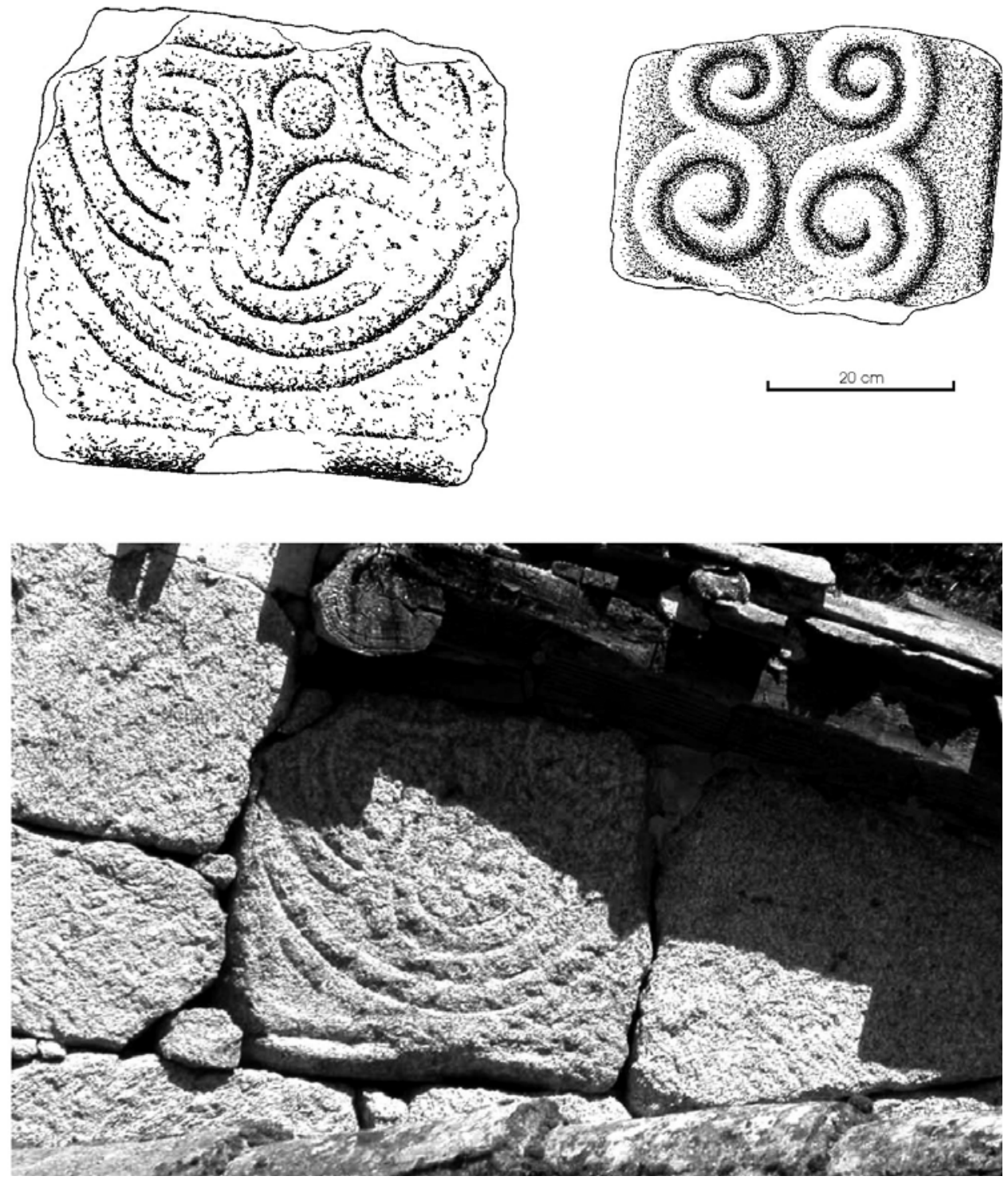

Figura 10. Tetrasquel moi erosionado (foto e debuxo) e fragmento de cronoloxía quizais dubidosa (arriba á dereita).

vado é tamén excepcional, recordando quizais en relevo a decoración de pezas metálicas coma o torques de Vilas Boas (Castro 1990: 167). Presenta un interesante fogueado no extremo superior, o que denota que, coma moitas das pezas que 

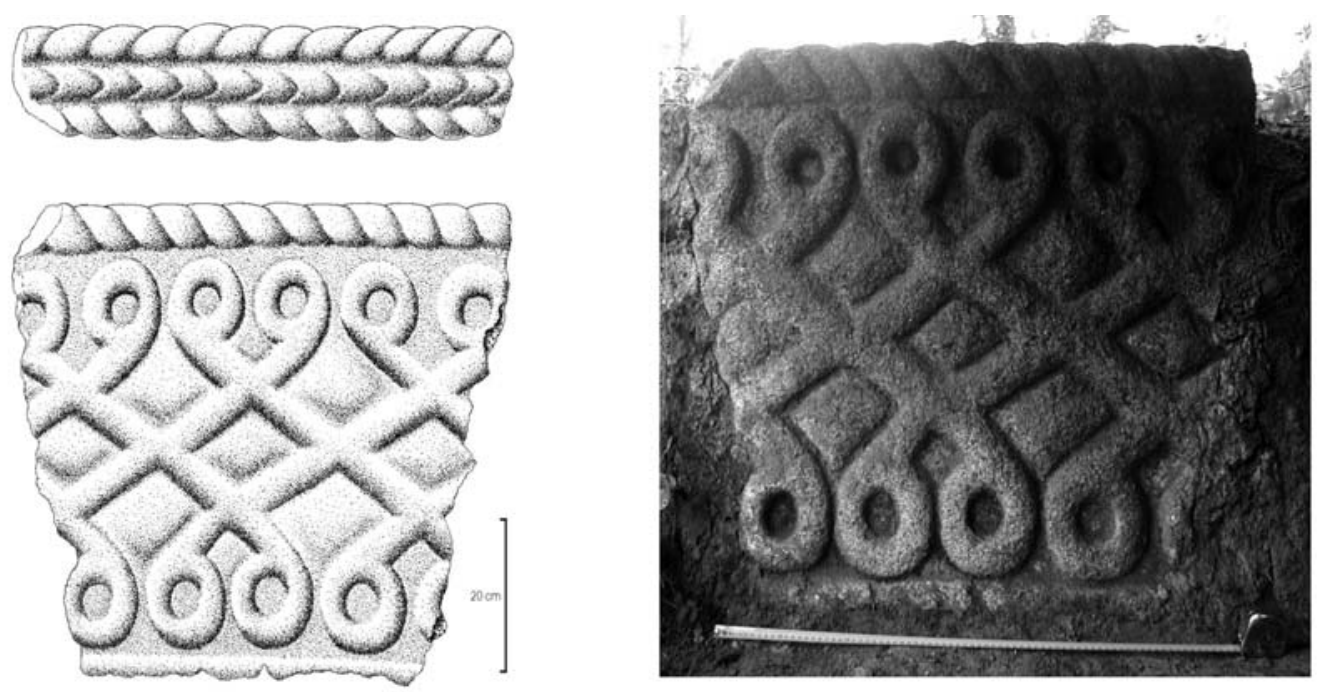

Figura 11. A pedra decorada no lavadoiro da Fontefría.

estamos a tratar, formaría parte non dun muro senón dalgún tipo de vano (porta ou similar). A tipoloxía ou mesmo a execución técnica deste altorrelevo deixan poucas dúbidas sobre o seu carácter «castrexo», aínda que é obvio que motivos xeométricos máis ou menos semellantes poden aparecer na arte popular en contextos moi diversos (Figura 12). Non obtivemos información que nos permitise contextualizalo. Tampouco apareceron máis exemplos no mesmo lugar da Fontefría. Tan só destacaremos que se atopa na fonte que dá nome á parroquia, unha fonte significativa e connotada simbolicamente, polo tanto, na que as poucas mostras de antigüidade que lle quedan foron enmascaradas por unha restauración realizada en época franquista. Pola disposición dos elementos da fonte e lavadoiro, semella que a pedra decorada foi colocada no seu lugar no transcurso desa última «restauración». Non sabemos se a pedra formaba parte da fonte xa con anterioridade.

Na parroquia da Fontefría agardaban aínda outras novidades. A lectura de Rivas Fernández (1972) guiou os nosos pasos ata a capela de San Xiago (pronuncia popular de San Xiao), na mesma parroquia pero bastante alonxada do lavadoiro antes descrito. O artigo dicía que alí se conservaban varias pedras de «tipoloxía castrexa»e unha ara ós Lares Viais. Visitámola no mes de Xuño do ano 2003.

Un rasgo curioso desta capela, común coa capela do Formigueiro, é que ámbalas dúas teñen tódolos lados desiguais (Seara Carballo 2002: 143; Rivas Fernández 1972: 303). Os fragmentos decorados máis importantes sitúanse nos laterais sur e 


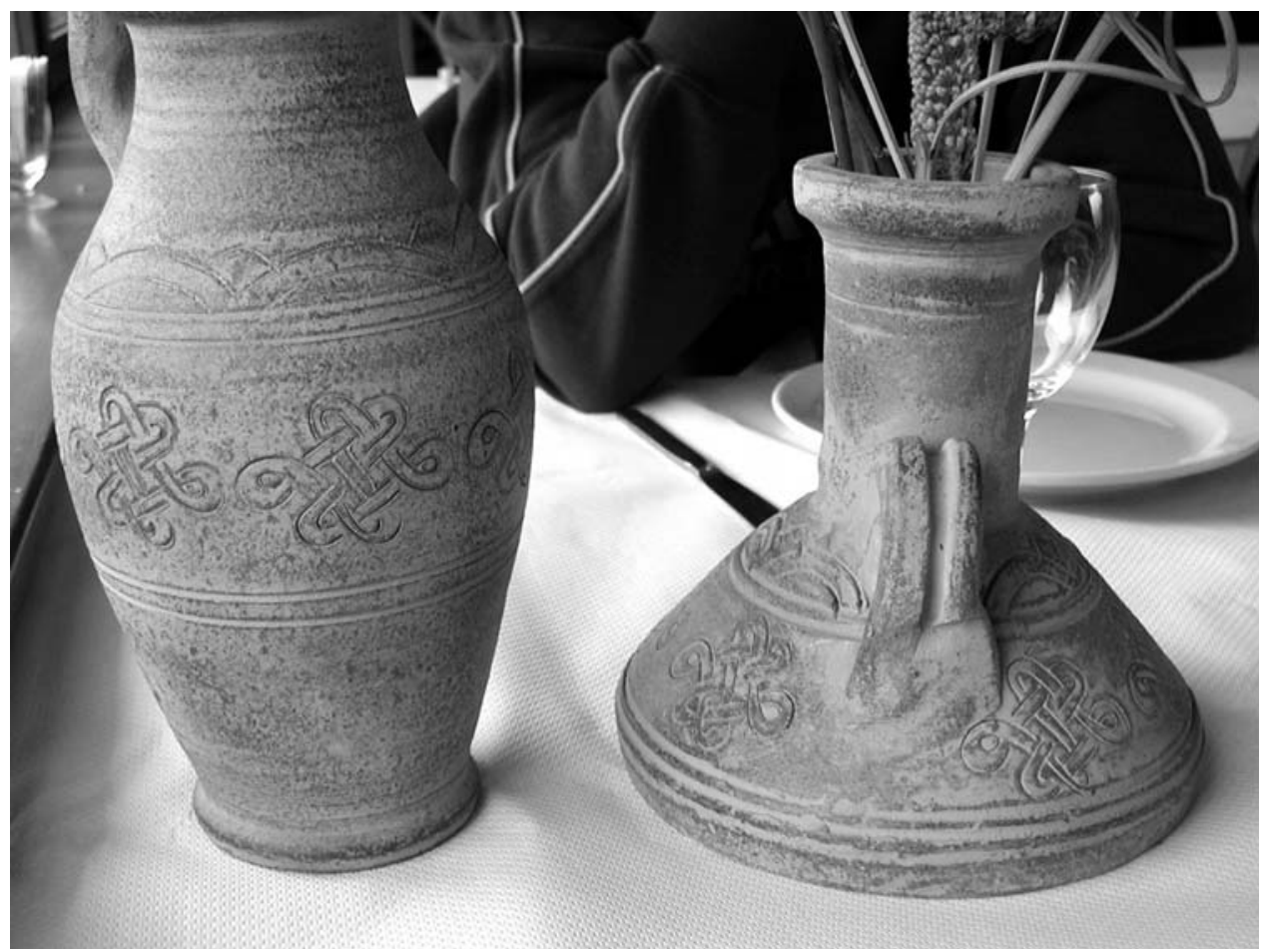

Figura 12. Cerámica decorada nun restaurante de Arrabaldo, Ourense.

leste (Figura 13). Outras tres pedras dos muros, a lo menos, están reaproveitadas, amosando rebaixes de funcionalidade incerta. No interior puidemos observar que a ara aparecía desprazada (no 1972 estaba situada á dereita da porta, agora á esquerda), sendo moi complicada a súa lectura por un recente «lavado», pero seguía facendo as funcións de pía da auga bendita en posición invertida respecto á inscrición epigráfica, tal e como sucedía nos anos setenta. As paredes interiores xa non están encaladas, como estaban no 1972, pero non fomos quen de detectar ningunha das «sorpresas» que Rivas Fernández esperaba. Xa destacou este autor a excepcionalidade artística do retablo e dos santos da capela, coma tamén sucedía no Formigueiro.

A tipoloxía castrexa dos dous fragmentos principais ten sido convenientemente xustificada noutras publicacións (Rivas Fernández 1972; Castro i Estévez 2003), comparándoa coas famosas xambas de Briteiros e cun fragmento da cividade de Áncora. Rivas Fernández, de feito, manifestaba as súas dúbidas, pero tamén dicía que na opinión segura de Ferro Couselo e Xaquín Lourenzo «los dos bloques deco- 

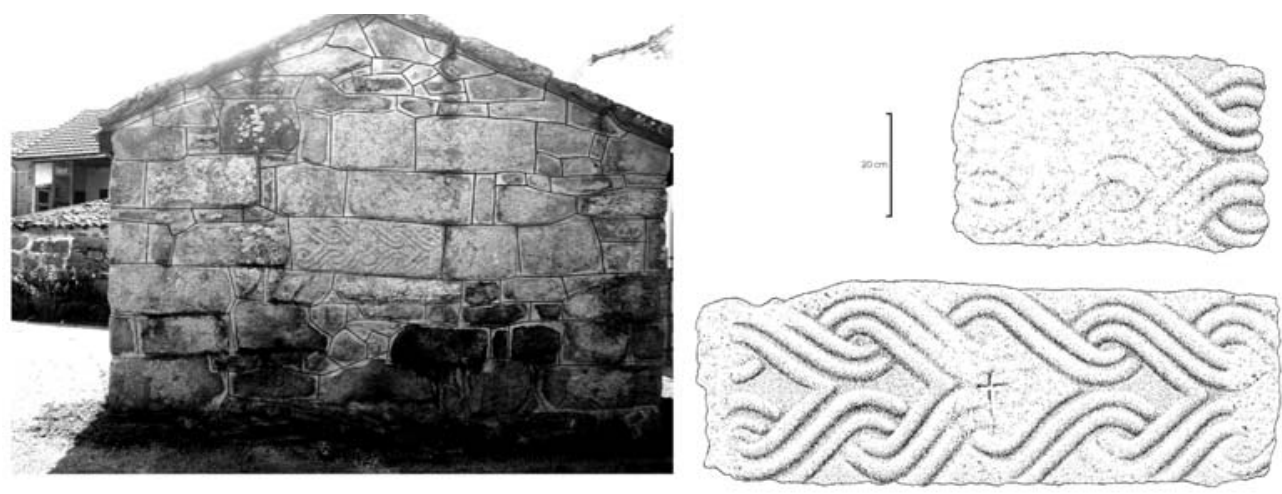

Figura 13. Pedras decoradas na capela de San Xiao.

rados proceden de algún habitáculo castreño cercano» (Rivas Fernández 1972: 307). «Sólo nos resta decir que, empotrados en los viejos muros de una cuadra inmediata, se encuentran dos toscos sepulcros antropoides, seguramente restos de la probable necrópolis primitiva de esta capilla» (Rivas Fernández 1972: 311).

\subsection{Os «cabezóns»}

Daqueles dous sartegos non chegamos a ter noticia, pero a fortuna puxo ante nós un novo achado inédito no lugar de San Xiao. Ante o noso interese pola capela, un veciño ofreceunos amablemente visitar unha vella casa propiedade da súa familia ( «a casa das tías Casildas»), onde se gardaban restos que el consideraba aínda máis interesantes. Eran o que el denominaba os «cabezóns» (Figura 14, esquerda), dúas caras gravadas na rocha no interior daquela casa, formando parte de dous piares graníticos, un deles na estrutura dun antigo pozo. As dúas «cabezas» estaban acompañadas duns extranos relevos e rebaixes noutras dúas pedras, que nunha primeira impresión interpretamos como podomorfos. Sen embargo, a súa simplicidade fai difícil soster tal afirmación, aínda que non a desbotamos por completo. Trátase de tres rebaixes de forma elíptica (os supostos «podomorfos») e unha cazoleta circular da mesma profundidade. Atópanse a ámbolos dous lados da cara máis toscamente gravada, por baixo dela (Figura 14, abaixo á dereita). Tanto a súa función coma a procedencia son descoñecidas.

Posteriormente, durante o proceso de documentación das «caras», advertimos a existencia dun terceiro «cabezón» (Figura 14, arriba á dereita). Bastante semellante a un dos previamente coñecidos, o fragmento pétreo fora empregado para tapar 

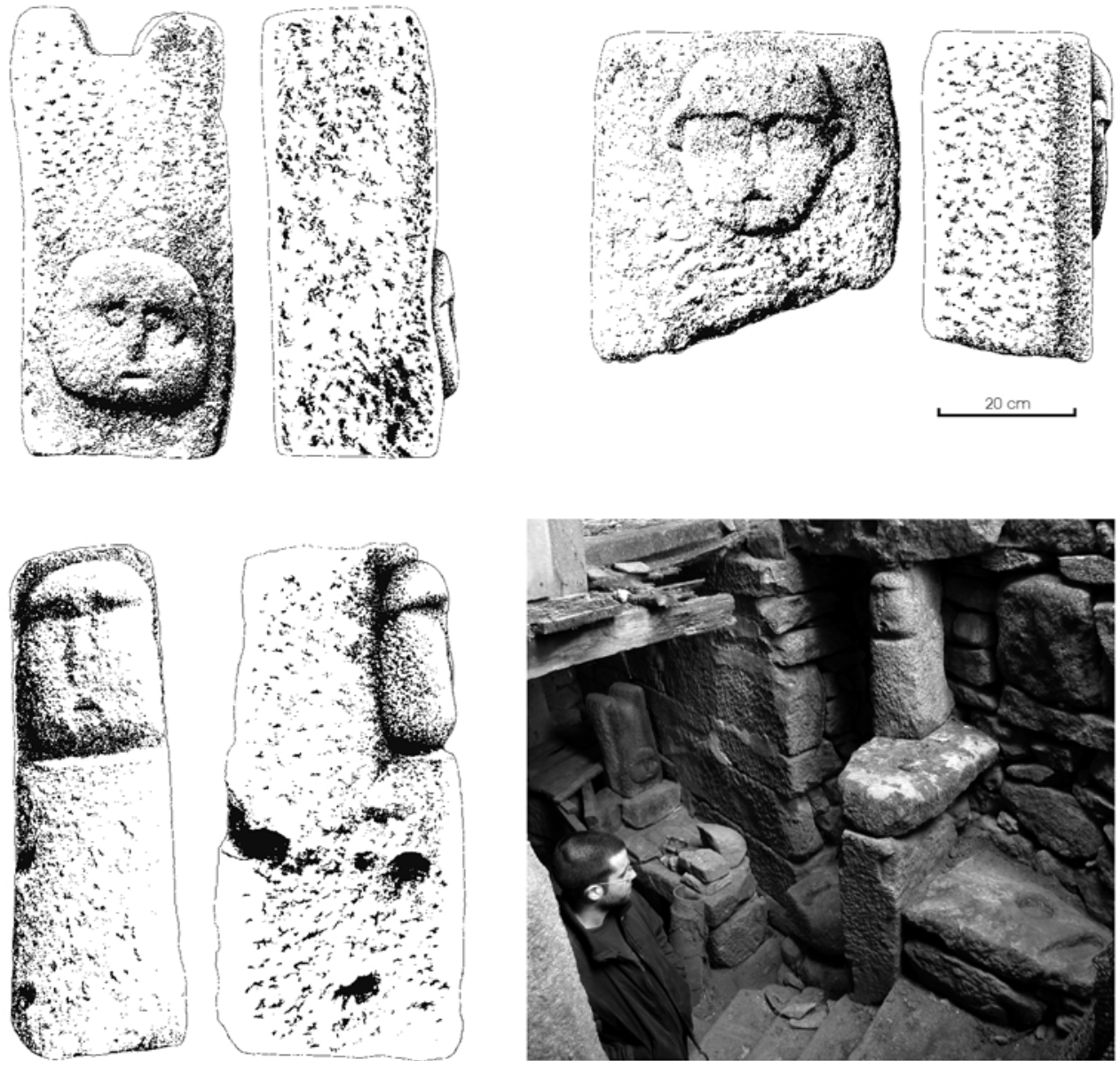

Figura 14. Os «cabezóns» da «casa das Tías Casildas», en San Xiao, Amoeiro.

a saída dun can por baixo da porta, dado que os donos da casa non perceberan, por causa da erosión, o seu gravado.

A tipoloxía destas caras é diversa: dúas delas manifestan unha certa semellanza en comparación coa terceira, moito máis esquemática que as outras. Nós sostemos, sen poder aseguralo, que é posible que se trate de pezas de tipoloxía «castrexa», tal e como definiamos este concepto ó comezo do artigo. A hipótese xurde pola posibilidade de que procedan do mesmo lugar que as pedras decoradas e a ara romana da capela, aínda que temos en conta a precaución exhibida por, entre outros, Calo Lourido (1994: 703-25) ou Blanco Freijeiro (1956: 53). Non pretendemos elaborar 
neste texto unha tipoloxía exhaustiva sobre as caras gravadas na pedra nos castros galegos, pero si apuntar algunhas posibilidades comparativas. Podemos sinalar, por exemplo, que os «cabezóns» da «casa das tías Casildas» aparecen, en tódolos casos, sobre soportes en forma de piar de sección cadrada, colocadas en sentido vertical, especialmente dispostas para ser contempladas, probablemente coma parte dalgún tipo de xamba, porta ou similar. É o tan traído e levado senso «apotropaico» das caras humanas, que non se reduce á plástica protohistórica: tamén é frecuente, por exemplo, na plástica románica (coma en Santiago de Allariz, en santo Tomé de Serantes ou na Santísima Trindade de Ourense, por citar exemplos próximos). Cuevillas falaba dunha certa sensación transmitida por estas figuras: era o que el chamaba a «cara de morto», sensación que apreciamos a lo menos nun dos nosos exemplos (Figura 14, arriba á esquerda). A do castro de Narla (Blanco 1956), tan criticada por Calo Lourido, é parcialmente semellante á da figura 14 (abaixo á esquerda) sobre todo por estar tamén adosada a un piar. Cabería a posibilidade de que as dúas caras de tipoloxía máis ou menos similar (Figura14, arriba) sexan da mesma man e cronoloxía e a última, a máis tosca, fora esculpida (quizais en tempos máis modernos) coa idea de substituír á que se conservaba, ignorada, baixo da porta da casa. Son, en todo caso, as primeiras hipóteses de traballo.

Sobre o tema das «cabezas trofeo» nas culturas célticas tense verquido ampla bibliografía (por exemplo Taracena 1943). López Cuevillas consideraba en 1951 que os rostros esculpidos en baixo relevo e asociados a castros eran «caras de mortos» e xa as relacionaba coas «tètes coupées» provenzais (López Cuevillas 1951: 195-7, 202). Tamén podemos lembrar as fibelas de cabaliño con cabeza de inimigo nas culturas celtibéricas. Hai estudios clásicos sobre as imaxes de caras e cabezas nas culturas europeas, coma o de Benoit (1955) para os impresionante santuarios de Entremont e La Roquepertuse. O importante destes exemplos para o noso caso é que, en case tódolos casos, as cabezas, caras ou ocos para cranios aparecen sobre columnas ou piares de pedra empregados a xeito de pórtico ou entrada ${ }^{17}$. O feito de que as tres caras de San Xiago estean construídas sobre piares, máis ou menos do mesmo tamaño ou grosor (aínda que poidan estar fragmentados ou retocados) é un rasgo importante que non deixa de suxerir un paralelo con algúns dos exemplos ligures (Benoit 1955: 42-3). Citaremos, por último, os extraordinarios paralelos etnográficos aportados por Abraira Pérez (2005) para varios santuarios cristiáns da provincia de Lugo. Á vista deste artigo, quizais a comparación etnográfica sexa aínda máis frutífera que a comparación arqueolóxica.

\footnotetext{
${ }^{17}$ Poderiamos aducir tamén que a decoración castrexa da capela de San Xiao semella ser unha decoración típica para portas, coma sucede no caso de Briteiros.
} 
Sen dúbida, pagaría a pena un estudo polo miúdo das tipoloxías destas caras e mesmo unha prospección sistemática polas casas do entorno, á busca de novos exemplos ou indicios. Deixamos aberta e pendente de confirmación a hipótese do seu carácter «castrexo» ${ }^{18}$.

Os donos da casa (a quen agradecemos a súa hospitalidade) recordaban os «cabezóns» «dende sempre» pero descoñecían a súa procedencia. Por un lado, pensaban que quizais poderían ser obra dun vello antepasado do que se dicía fora canteiro. Por outro lado afirmaban que, en xeral, a pedra empregada na vila tiña a súa orixe no «castelo» do Rodeiro que se divisaba na distancia. Para eles, tódalas pedras decoradas da vila poderían proceder daquel lugar, onde estaba a canteira tradicional da maioría dos lugares próximos e do propio San Xiago. Algúns tamén dicían (ante a incredulidade doutros) que naquel «castelo» (ou o que fose) tiñan aparecido, tempo atrás, «potas e sarténs», que había mesmo «casas» ou «muros», onde eles xogaban de meniños, pero que hoxe probablemente xa non existían.

\subsection{O posible castro do monte Rodeiro}

As nosas pesquisas encamiñáronse, consecuentemente, á busca dun castro no monte do Rodeiro. Sobre a ladeira sur deste monte recollemos a noticia da existencia dunhas sesenta mámoas, das que trinta foran desfeitas por traballos de cantería e para facer un campo de fútbol. Sexa ou non plausible tan elevada cantidade, o certo é que destas mámoas xa falaba Otero Pedraio: «nos ermos do Rodeiro téñense sinalado (por Florentino Cuevillas) vestixios de mámoas» (Otero 1927-8; n. ${ }^{\circ} 52:$ 69).

A bibliografía recolle tamén un par de indicios sobre o hipotético castro do Rodeiro. «Poucos cotos do Rodeiro teñen nome. Un dos que s'erguen xa na baixada ô nivel mais baixo e fondamente labrego dos Chaos, leva o de Castro e n-il ten recoñecido Florentino L. Cuevillas o prestixio arqueolóxico que sempre é confirmado pol-o nomeamento do pobo» (Otero 1927-8; n. ${ }^{\circ} 46: 5$ ). En 1972, Ferro Couselo recibía a nome do museo arqueolóxico de Ourense unha lousa granítica cun onomástico que procedía «según informes no muy precisos» dun castro nas proximidades da parroquia de Abruciños. I engade «a lo que podemos calcular, en el Castro do Rodeiro, sito ya en la parroquia de Trasalba» (Ferro Couselo 1972: 336).

O 14 de Maio de 2004 puidemos constatar a incrible desfeita provocada na zona polas labores de pedrería, que xa documentara Otero Pedraio falando das forma-

\footnotetext{
18 Para quen teña vontade de proseguir coa investigación sobre «cabezas cortadas» contaremos (coa boca pequena) que o mártir San Xiao, homónimo da capela e lugar onde se atopan os «cabezóns», morreu degolado na compaña de San Ferreol, atopándose incorrupta a súa cabeza (Benoit 1955: 58; Vorágine 1982: 142; Ferro Ruibal 1992: 544-7).
} 
cións de coviñas e pías naturais no Rodeiro e da laboura dos canteiros como extraordinario axente erosivo: «algús cotos están cuase desfeitos pol-os canteiros» (Otero 1927-8; n. ${ }^{\circ} 48: 7$ ). En efecto, polos datos que puidemos obter, a cantería tivo unha importancia moi destacada no lugar i, en concreto, durante o século pasado viuse concentrada no Coto do Castelo, cuxa pedra foi amplamente exportada con fins comerciais. O Coto do Castelo é ademais o referente paisaxístico do Chao occidental, visible dende a práctica totalidade da zona e auténtico fito para a organización territorial das sociedades tradicionais. En certo modo, o Coto do Castelo cumpre unha función similar á que cumpre o San Trocado na outra ribeira do Barbantiño, destacando non só sobre o penichán, senón tamén no discurso do Miño. Consideramos que estes dous fitos paisaxísticos poden ser fundamentais para entender a organización do poboamento e a articulación deste territorio.

Pese a tódolos indicios, os resultados da nosa busca arqueolóxica non foron excesivamente concluíntes: o topónimo «castelo» persiste a día de hoxe (xunto a outros topónimos entre os que destacamos o de «O Corvo»), pero os datos que puidemos obter sobre a localización toponímica concreta foron sempre un tanto ambiguos. Por engadidura, non puidemos documentar ningún xacemento claramemente «castrexo». Nun pequeno saínte da ladeira que mira a Trasalba atopamos varias terrazas e un pequeno chozo construído para resgardo dos canteiros e da súa ferramenta. Estes aterrazamentos poderían ser froito da actividade histórica, se ben non descartamos a localización neste esporón dun posible asentamento prehistórico.

Outro aspecto salientable da prospección foi a localización precisa do «camiño real» que pasa ó pé do monte Castelo e a constatación da afección que as obras do tren de alta velocidade terán sobre o seu trazado. Nas palabras de Otero: «a tradición costante de Trasalba fala d'un camiño que dend'os fondales do Medelo, levaba pol-a rexión dos Chaos da parroquia e pola veiga d'Albeiros hastra o dito coto do Formigueiro. Os habitadores, d'aquela mouras, ían pol-a estrada pra mercar a carne ó coto onde tiñan o despacho: mail'a tradición non siñala cidade nin tampouco a toponimia. Os paisanos vellos falaban d'haber atopado moitos anacos de ladrillos da dita estrada; mais por sere terreo moi labourado hoxe non se pode procurar ningún» (Otero 1927-8; n. ${ }^{\circ}$ 52: 69).

\subsection{Outros achados en Amoeiro}

Seguindo co recoñecemento arqueolóxico, localizamos un novo asentamento castrexo entre A Fontefría e O Formigueiro, con varios aterrazamentos en torno a un pequeno alto, parcialmente afectado por unha liña de alta tensión (inédito castro da Poboanza ou da Mourexa). Pero o achado máis sorprendente produciuse moi 

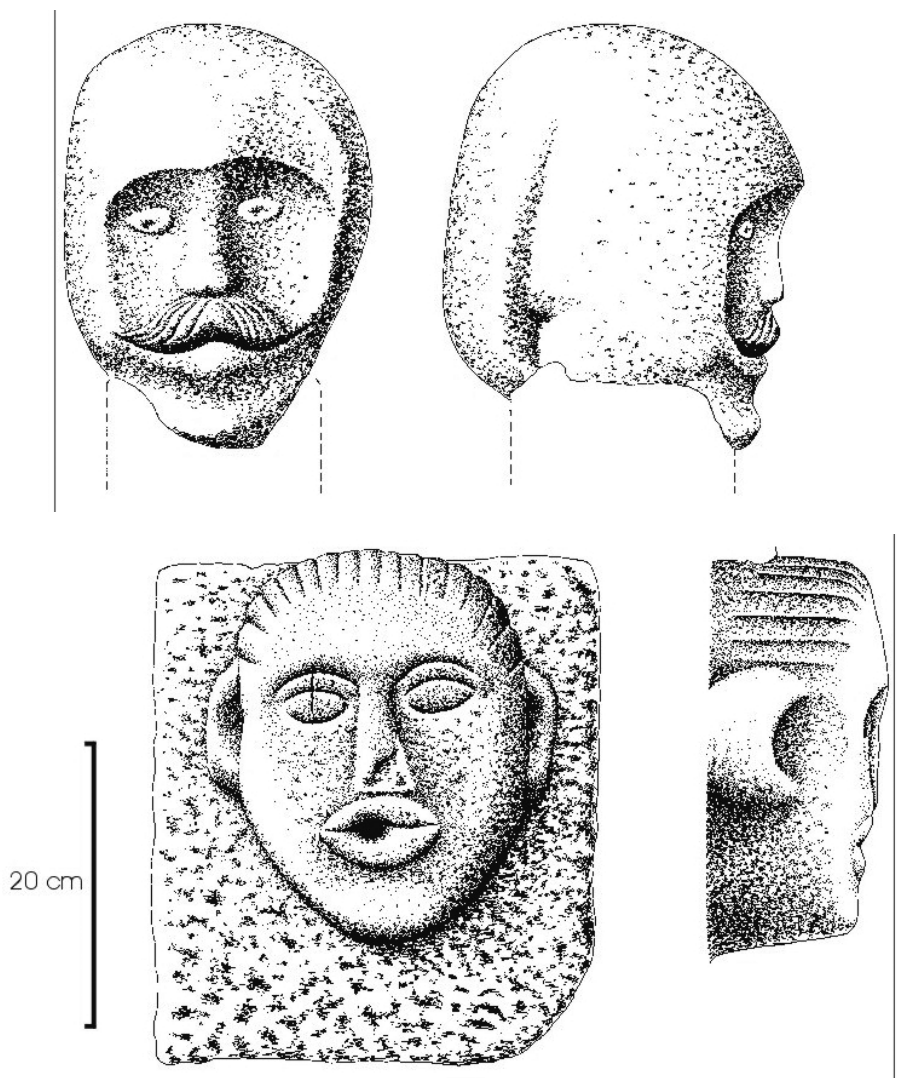

Figura 15. Outros «cabezóns» en Amoeiro. Enriba, nunha entrada dunha casa particular preto do Formigueiro. abaixo, no muro exterior do ábside da parroquial de Trasalba.

preto do Formigueiro. En Xuño do 2004 atopamos un novo «cabezón» ante o portalón de entrada á finca dunha vivenda, adornado cunha sorte de «coroa» e pintado de vivas cores. A súa posición semellaba remitir a funcións «apotropaicas» e a testemuña do seu propietario non deixa lugar a dúbidas: «ter isto aquí é coma ter á garda civil» (Figura 15, enriba). De tipoloxía ben diferente ás de San Xiao, atopábase na «casa da Cubela» ${ }^{19}$. Esta vivenda é excepcional por varias razóns: na entrada aparecía o «cabezón» reutilizado cun fin apotropaico, pero na propia cerca da

\footnotetext{
${ }^{19}$ A casa está ó lado dunha grande «cubela», presa ou poza moi probablemente asociada (en orixe) ó castelo do Formigueiro, dotada de varios muíños e mesmo un de enorme tamaño, do que só se conserva un grande rodicio de tipo vertical case desfeito.
} 
finca aparecía, enriba de cada poste, un anaco de wolfram colocado quizais coma recordo do traballo na mina. Entre outros artefactos antigos empregados con fin decorativo destaca tamén un fermoso xugo decorado cunha rosácea.

É obvio que a tipoloxía desta peza non se pode remontar miles de anos con facilidade, como sucedía no caso das de San Xiao ${ }^{20}$. Pero o que chama a atención poderosamente é o seu emprego, a súa posición, o seu carácter simbólico. Existe aínda unha última «cabeza» que debemos mencionar, desta volta de cronoloxía probablemente moderna e adosada ó ábside da igrexa parroquial de Trasalba (Figura 15, abaixo). Probablemente teña sido reaproveitada dúas veces (a primeira, nunha fonte, porque o burato semella posterior á confección da peza). Como a anterior, tampouco é «castrexa», pero, de novo, ostenta unha función simbólica significativa, situada nun lugar relixioso de preferencia, illada no muro e mirando ó camposanto.

\subsection{A casa reitoral de Santiago de Anllo}

Tódolos achados que temos amosado ata o de agora concéntranse en poucos quilómetros, no propio concello de Amoeiro. Non obstante, do outro lado do Barbantiño tamén hai pedras decoradas.

Nunha visita á igrexa de Santiago de Anllo (San Amaro), datada no século XVII, atopamos unha nova e tripla (ou cuádrupla) reutilización ${ }^{21}$. Na entrada traseira da casa reitoral deste lugar atopamos varias pezas reutilizadas nun minúsculo recinto de funcionalidade incerta (Figura 16). A plástica das tres pezas decoradas semella ter diferente cronoloxía: no teito e colocada cara a abaixo, unha tampa de sartego de tipoloxía altomedieval («de dobre estola») (Figura 16, número 1); no fondo da cámara, formando o central de tres pequenos «estantes», un pequeno «capitel» con decoración case con seguridade románica (Figura 16, número 4); no exterior unha grande peza decorada, en parte semellante á da capela do Formigueiro (Figura 16, número 3). Hai ademais outra pedra, na parte superior e ó lado do sartego, cun rebaixe (Figura 16, número 2) que quizais podería formar parte dunha porta.

A pedra decorada cara ó exterior é a máis monumental. Presenta unha decoración bastante diversa, xeométrica na súa maioría pero que inclúe dúas figuras: un

\footnotetext{
${ }^{20} \mathrm{O}$ seu propietario afirmou ter mercado a peza a un veciño seu nunha parroquia do concello de Portomarín (Lugo), xa que se atopaba orixinalmente encastrada no muro de pedra que pechaba unha leira. Esta reutilización como material construtivo pode indica-la antigüidade do busto e non descarta necesariamente unha posible adscrición á protohistoria ou antigüidade.

${ }^{21}$ Pedimos públicas desculpas ó dono da propiedade, o párroco de Anllo, por documentar as pezas na súa ausencia.
} 

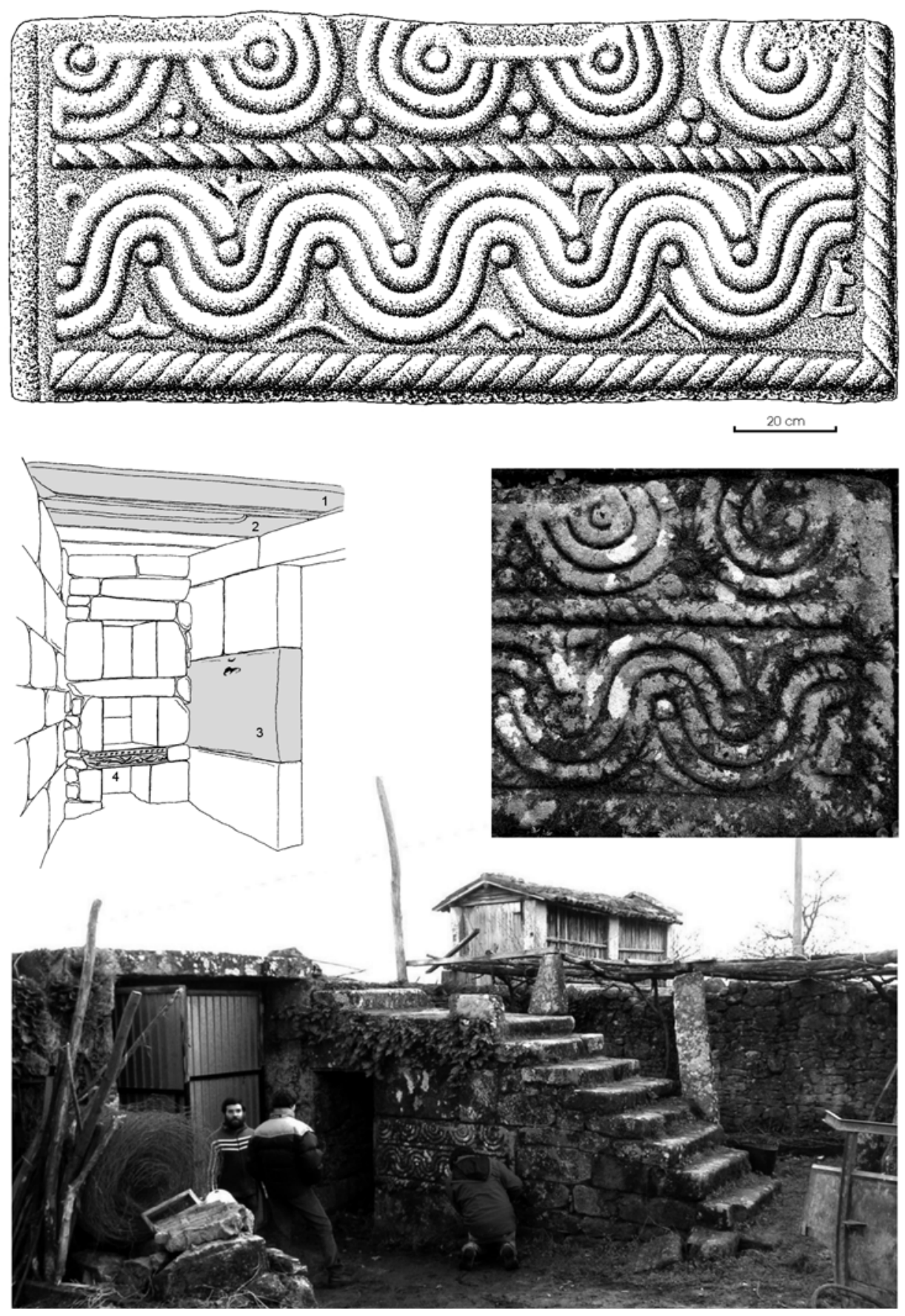

Figura 16. Pedras reutilizadas na entrada traseira da reitoral de Anllo (San Amaro). 
zoomorfo e un posible antropomorfo, no sector inferior dereito (Figura 16, centro dereita). A cronoloxía desta peza é difícil de determinar segundo a tipoloxía (¿castrexa ou medieval?), se ben o deseño xeométrico presenta unha certa «inspiración ou tradición antiga», sobre todo no característico friso de SSSS entrelazadas.

É tamén moi interesante o feito da tripla reutilización e o propio recinto onde as pezas se sitúan. Para chegar ó mesmo hai que percorrer un camiño complicado, por detrás da igrexa, baixo un arco, e, deixando a casa reitoral á esquerda, avanzar por un angosto carreiro que remata pasando baixo un hórreo e, virando á esquerda, dá paso á entrada traseira da casa reitoral, un fermoso exemplo de arquitectura de época moderna. Nesta entrada, mirando á esquerda dende a porta, o recinto descrito forma un pequeno habitáculo que serve de sostén das escaleiras que dan acceso ó cabaceiro antes citado. Incluímos unha foto xeral e un esquema da posición das pezas no cubículo (Figura 16) para clarexar a descrición e facer patente a súa excepcionalidade. Hoxe en día, esta entrada é unha entrada marxinal e oculta, aberta ós campos de cultivo, pero quizais no seu tempo fose unha das entradas principais da casa. En calquera caso, a súa posición liminal indica unha vontade de visibilidade (ou exhibición cara a fóra) da grande peza decorada.

\section{A FUNCIÓN SIMBÓLICA DA REUTILIZACIÓN DA CULTURA MATERIAL NA SOCIEDADE RURAL TRADICIONAL}

A reutilización é, sen dúbida un proceso moi complexo, tradicionalmente xustificado por criterios de custo aínda que nel tamén subxacen contidos simbólicos e sociais. Castiñeiras (1989-90) discute o concepto de «reutilización progresiva»: para o prerrománico, por exemplo, establece un vencellamento co fenómeno da repoboación e cunha «continuidade entre santuarios romanos e oratorios cristiáns» (Castiñeiras 1989-90: 78). Cita, por exemplo, a reutilización de sartegos romanos no medievo, falando tamén dunha certa especificidade da estética popular no mundo rural. Para a época suevo-visigoda, onde se reutilizan restos romanos moitas veces con senso sacro, cita os casos de Santa Eufemia de Ambía, Bande, Mixós ou San Adrián de Amiadoso. Son moi significativas as reutilizacións de sartegos para novos enterramentos, onde coexiste a reverencia sacra do pasado coa mitoloxía popular, como sucede no caso do sarcófago de San Wintila. En San Xes de Francelos hai asimesmo outro interesante caso de reutilización de pedras decoradas en varias casas próximas á capela: algúns deles forman motivos sogueados parcialmente semellantes ós presentados neste artigo, pero a súa tipoloxía é moito máis claramente medieval (Lorenzo e García 1950: 377 e lám. VII). Tamén se distingue 
polos seus traballos sobre reutilización Rivas Fernández, o autor que deu a coñecer por primeira vez o caso de San Xiao, e que fala tamén de reutilizacións de restos prerrománicos en capelas ourensáns (Rivas Fernández 2003). No caso das caras ou cabezas humanas hai casos moi interesantes de reutilización, coma o citado por Bouza Brey (1953: 33) para a cabeza «céltica» de San Mamede do Castro (Silleda). En 1946 un desmonte de estrada propiciou o achado de cerámica, muíños de man e «la escultura objeto de esta nota, la cual fue recogida por un vecino, que la colocó en lo alto de una tapia, a la entrada de su huerto». Foi exactamente o mesmo que nós puidemos atopar na «Casa da Cubela», aínda que neste caso, como xa dixemos, a tipoloxía da figura non teña nada que ver coa tipoloxía das caras supostamente «castrexas» (Figura 15, enriba). Outro paralelo moi interesante é o da cabeza/piar de Pfalzeld, Bonn, que «se ha conservado, como otros monumentos de la misma especie, porque los campesinos, temerosos de su fuerza mágica, lo trasladaron desde su emplazamiento original a la proximidad de la iglesia de Pfalzeld» (Blanco Freijeiro 1956: 58). O mesmo sucedeu coa cabeza reutilizada no ábside da

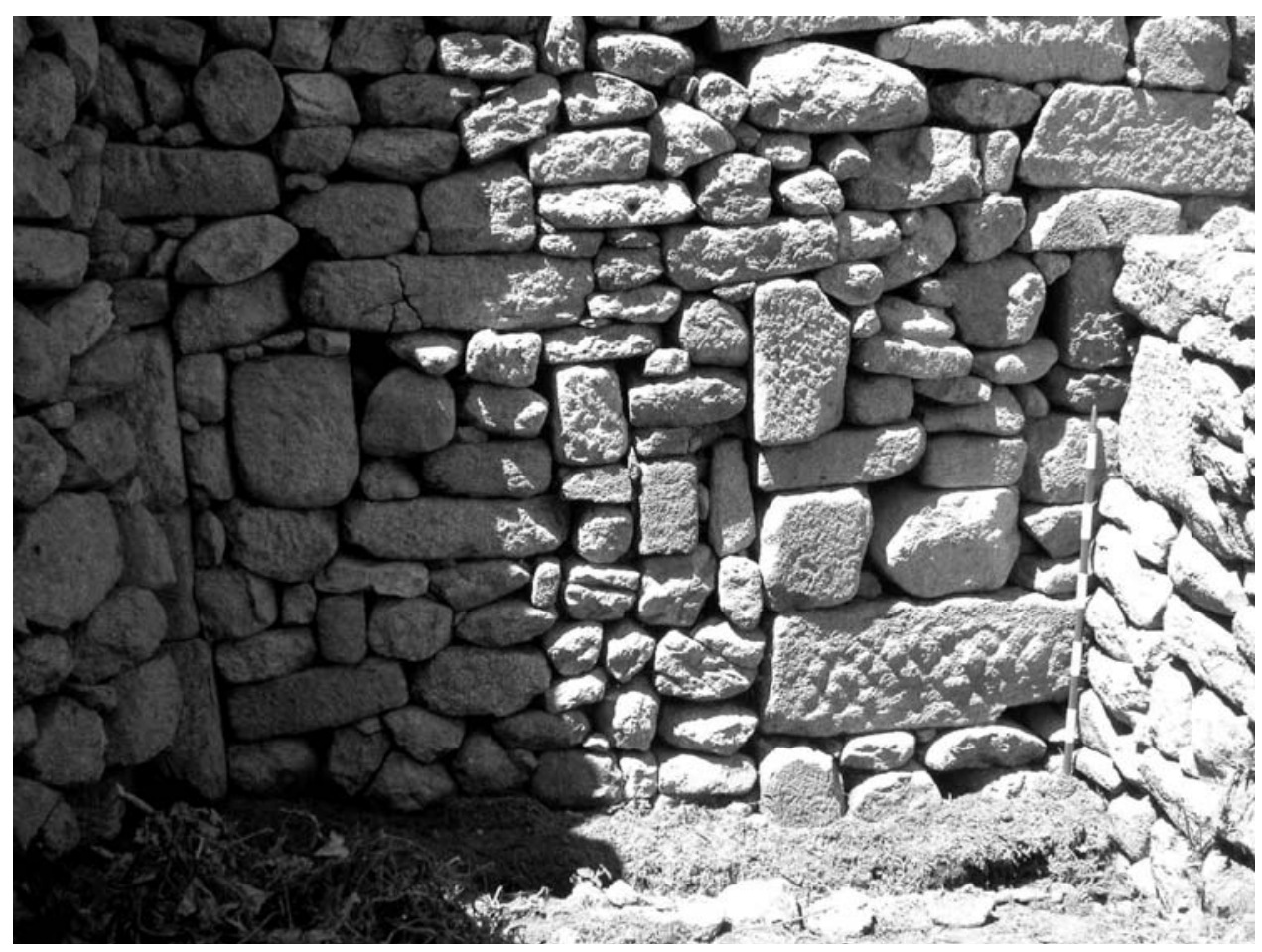

Figura 17. Un lenzo de muro no Formigueiro (Amoeiro), á dereita un reticulado e unha basa de columna. 
igrexa de Trasalba e o mesmo sucede coa maior pedra decorada da capela de San Xiao: a posición destas dúas pezas, no muro traseiro de cadanseu santuario, perfectamente centradas, reivindica un certo compoñente decorativo pero tamén sacra por estar situadas xusto tralo sagrario. Algún cura do lugar gravou unha cruz xusto no medio da peza de San Xiao (Figura 13, centro) coma ilustrando un exemplo perfecto de reiterada cristianización.

Outro feito a destacar é que na maioría das construcións onde aparecen pedras decoradas ou «cabezóns» aparecen tamén outros elementos construtivos reutilizados, polo que ás veces a reutilización semella simplemente «práctica»: as pedras non se empregan polo seu senso decorativo nin simbólico, senón para encher muros. Non obstante, cremos que na maioría dos casos si aflora un certo elemento simbólico. É moi ilustrativo, por exemplo, o cambio de ubicación da estela do Formigueiro, que pasou de formar parte da mesa do altar, no interior e con motivos invisibles, a unha exhibición pública como elemento da portada, exterior e moi visible. De feito, esta exhibición, segundo afirman os propios habitantes do Formigueiro, foi unha forma de reivindicar a propiedade comunal da pedra. O friso da Fontefría (Figura 11) aparece tamén nun espazo comunitario. Os cabezóns teñen un forte senso monumental e simbólico en tódolos casos: todos eles están situados para ser vistos, en exhibición pública/común ou privada/familiar, para separar e marcar un espazo ou un tránsito determinado (unha entrada, unha escaleira, un ábside). Tamén sinalan posicións centrais (ábside e dintel) as maiores pedras das capelas de San Xiao e O Formigueiro (figs. 13 e 5). Algunhas das pedras decoradas reutilizadas nas adegas do Formigueiro cumpren a mesma función, situándose no centro das paredes, nos lugares máis visibles ou ó lado de portas. O grande reticulado da Figura 17 está ó lado dunha antiga porta, mentres no interior (xunto ó case imperceptible trisquel) ocupa o centro do actual muro. Na mesma casa, un tetrasquel sinalaba a cúspide máis visible da edificación no exterior (Figura 10, abaixo), nunha situación lixeiramente diferente tras unha recente reforma. Hai tamén casos nos que estas pedras reutilizadas parece que foron esquecidas, tapadas ou escondidas (¿censuradas?) formando parte de muros, pero esa impresión pode ser enganosa. A propia estela grande do Formigueiro estivo «tapada» baixo un altar durante moitos anos (¿cantos?), pero iso non fai máis que destacar o carácter altamente simbólico de tal ocultación «fundacional». Sen dúbida, é o da capela do Formigueiro o mellor exemplo de reutilización simbólica entre todos os presentados. Se consideramos que a estela prerromana quizais tiña significado relixioso podería ser este o único fenómeno de «paganización» contemporánea dun santuario cristián do que temos constancia. Pero non deixa de ser tamén curiosa a disposición do recinto ou cubículo no que se integran as tres pedras decoradas na casa reitoral de Anllo. A funcionalidade 
desta construción é para nós descoñecida: a única hipótese que podemos aportar, tendo en conta as implicacións funerarias do sartego, é que nese lugar se dispuxese algún tipo de santuario ou contenedor de reliquias (quizais no senso dos presentados por Abraira Pérez 2005). En calquera caso, a pregunta queda aberta.

Podríamos pensar na posibilidade de que tódolos restos estudados puidesen proceder dun único conxunto monumental con funcionalidade relixiosa, quizais do propio monte Castelo do Rodeiro. Outros especialistas consultados apuntan ó propio San Cibrán como lugar de procedencia dalgúns dos restos ou de todos eles. Nós consideramos que, sendo estas hipóteses válidas, as propias características dos achados nos levan noutra dirección. Pensamos que o debate sobre a localización orixinaria das pezas é bastante baleiro, pero tamén pensamos que hai que ter en conta a pervivencia das tradicións estilísticas ó longo da historia. O problema da «romanidade» da plástica castrexa, por exemplo, é máis ben un falso problema. En vez de crear compartimentos estancos e condenarse á súa defensa, máis valería indagar na pervivencia de manifestacións de «estilo castrexo» no mundo medieval, por exemplo. Podería ser plausible que esas características de estilo pervivan con máis forza nas rexións onde foron orixinadas ou alcanzaron un maior desenvolvemento, é dicir, nos entornos dos oppida. Noutro contexto, os estilos arquitectónicos árabes perviven en maior medida nas zonas que estes poboaron máis aló do seu tempo. Diremos para finalizar que nos procesos históricos existen mecanismos de reutilización e reciclaxe, de continuidade en definitiva, que funcionan no eido conceptual, no eido técnico, no eido material, no eido simbólico e case en calquera aspecto que poidamos analizar. Sexa cal sexa a cronoloxía da elaboración e uso orixinal das distintas pezas que manexamos, hai rasgos específicos (a forma da palmeta de lira, o carácter decorativo do friso de SSSS, a función «defensora do lar» dos rostros humanos esculpidos) que amosan indicios de forte permanencia. Pensamos ademais que esa permanencia é debida a cuestións simbólicas moi importantes para entender a cultura campesiña tradicional galega e a súa relación co medio.

Hai aínda un último exemplo de reutilización que empregaremos como epílogo. Nas proximidades do castro de San Andrés de Beiro atópase o «Coto da Eira» ou «coto do castelo», un castelo do que se dicía, pola súa posición prominente (semellante á posición de San Andrés do Castro de Beiro), que era «a defensa de Ourense». O lugar exhibe hoxe unha reutilización cando menos peculiar. A «eira» á que fai relación o topónimo é a tradicional eira de mallar, como confesaron algúns habi- 
tantes do lugar. Hoxe en día esta eira foi convertida en «heliporto» por obra dun voluntarioso restaurador (Figura 18), que creou ex novo un santuario adicado á Nosa Señora da Saúde e ó Neno Xesús de Praga, combinado con símbolos como unha «roda da muiñeira» ou un carro do país decorado coa bandeira galega. Atopámonos cunha xenial escenografía postmoderna, produto dun proceso de redefinición da propia identidade do campesiñado rural, que sintetiza de xeito surrealista procesos fondos como a morte do modo de vida tradicional, a materialización dunha perspectiva folclorista que encapsula a tradición, o trauma que supuxo o trunfo da Modernidade, o impacto da emigración na cosmovisión e no patrón de racionalidade dos campesiños de Beiro. Unha vez máis, a cultura material, a apropiación de espazos simbólicos e a renegociación da identidade colectiva seguen a manifestarse a comezos do terceiro milenio como estratexias de construción da realidade social.

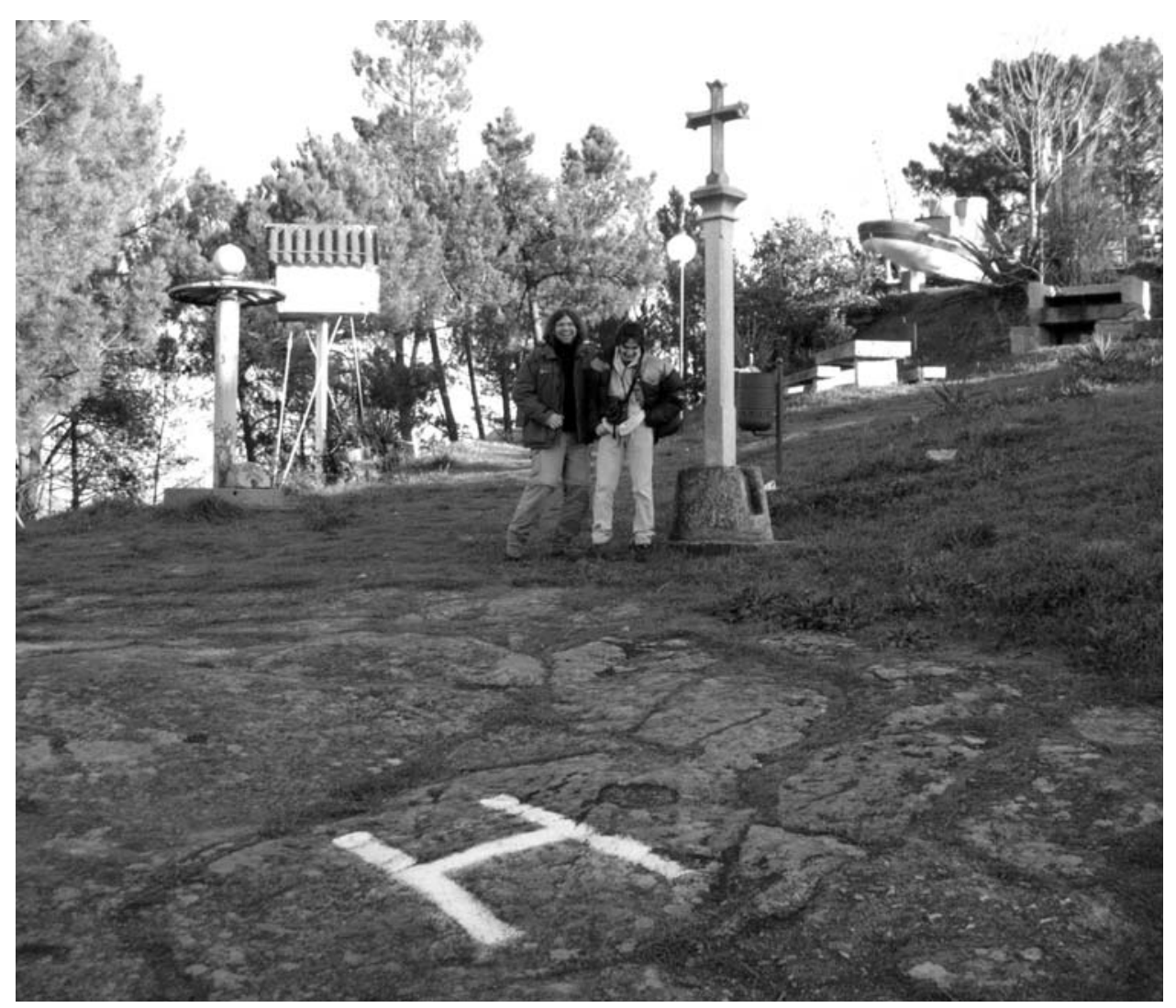

Figura 18. Unha eira de mallar convertida en heliporto en San Andrés do Castro de Beiro. 
O helicóptero na eira de mallar constitúe a mellor metáfora do voo da Modernidade na Galicia rural. Un voo que se fixo sen escalas. Fun polo vento, vin polo aire.

Á vista dos novidosos usos daquela antiga eira de mallar, non hai dúbida de que os procesos populares de «restauración» seguirán aportando máis achados a pouco que indaguemos. Estamos convencidos de que os paisanos coñecen e saben apreciar o seu patrimonio material. Tan só queremos desexar dende estas páxinas que as institucións e os individuos saiban poñerse de acordo para respectar e poñer en valor, da menos mala das maneiras, o patrimonio de todos.

\section{BIBLIOGRAFÍA}

ABOAL FERNÁNDEZ, R. e COBAS FERNÁNDEZ, I., 1999: La Arqueología en la Gasificación de Galicia 10: Sondeos en el Yacimiento Romano-Medieval de As Pereiras, Traballos en Arqueoloxía da Paisaxe 13, Santiago.

ABRAIRA PÉREZ, M. A., 2005: «La muerte de cara y la cara de la muerte. Empotramiento y exposición de cráneos humanos en tres recintos sagrados rurales de la provincia de Lugo. Análisis cultural», Gallaecia 24, 335-67.

ÁLVAREZ GONZÁLEZ, Y. e LÓPEZ GONZÁLEZ, L. F., 2000: «La Secuencia cultural del asentamiento de Laias: evolución espacial y funcional del poblado», Actas do $3 .{ }^{\text {er }}$ Congresso de Arqueologia Peninsular (1999, Vila Real), Porto, 523-530.

ÁLVAREZ GONZÁLEZ, Y., LÓPEZ GONZÁLEZ, L. F., LÓPEZ MARCOS, M. A. e LÓPEZ BARJA DE QUIROGA, P., 2004: «Dos inscripciones inéditas del Castro de San Cibrán de Las (San Amaro - Punxín, Ourense)», Palaeohispanica 4, 235-44.

AMADO REINO, X., MARTÍNEZ LÓPEZ, M. del C. e SANTOS ESTÉVEZ, M, 1998: La Arqueología en la Gasificación de Galicia 5: Corrección de Impacto del ramal Pontevedra-Ourense, serie TAPA, 7, Santiago de Compostela.

ARIZAGA CASTRO, Á. e AYÁN VILA, X. M., no prelo: «Etnoarqueología del paisaje castreño», en González García, F. J. (coord.), Los Pueblos de la Galicia Céltica, Madrid.

AYÁN VILA, X. M., 2005: «Etnoarqueoloxía e Microhistoria dunha paisaxe cultural: a parroquia de San Pedro de Cereixa», Cuadernos de Estudios Gallegos 118, 117-172.

AYÁN VILA, X. M. 2005a: «Os castros despois dos castros: un espazo simbólico na paisaxe rural tradicional galega», en Ballesteros Arias, P. (coord.), Encontros coa Etnografía, 63-136, Noia.

AYÁN VILA, X. M. e ARIZAGA CASTRO, Á., 2005: «Os Castros de Neixón como espazo simbólico na paisaxe rural tradicional (notas etnográficas e reflexións sociais)»., en Ayán Vila, X. M., 2005, Os Castros de Neixón (Boiro, A Coruña), 291-327, Noia.

BEJARANO, V., 1987: Hispania Antigua según Pomponio Mela, Plinio el Viejo y Claudio Ptolomeo, Fontes Hispaniae Antiquae VII, Barcelona.

BENOIT, F., 1955: «Le sanctuaire aux «esprits» d'Entremont», Cahiers Ligures de Préhistoire et d'Archéologie 4, 38-69. 
BLANCO FREIJEIRO, A., 1956: «Cabeza de un castro del Narla. Notas sobre el tema de la cabeza humana en el arte céltico», Cuadernos de Estudios Gallegos 11, 159-80.

BLANCO FREIJEIRO, A., 1958: «En torno a las joyas de Lebuçao», Revista de Guimarâes 68, 15596.

BOUZA BREY, F., 1938: «El grabado prehistórico de «O Coto das Ferraduras» en Cortegada de Miño (Orense)», Boletín de la Comisión Provincial de Monumentos Históricos y Artísticos de Orense $11,368-78$.

BOUZA BREY, F., 1951: «La cabeza céltica de Ocastro (Silleda)», Cuadernos de Estudios Gallegos $18,33-42$.

CABANO VÁZQUEZ, I., 1998: «Frei Hernando Ojea (1543-1615). Un libro sobre Santiago escrito en Nova España por un galego», Estudios Migratorios 5, 201-22.

CALO LOURIDO, F., 1994: A plástica da cultura castrexo galego-portuguesa, 2 vol., A Coruña.

CARBALLO ARCEO, L. X., 1996: «Notas en torno a cronoloxía do castro da Forca e da plástica castrexa. Minius V: 65-67.

CASTIÑEIRAS GONZÁLEZ, M. A., 1989-90: «La reutilización de piezas romanas y medievales en Galicia», Brigantium 6, 77-90.

CASTRO PÉREZ, L., 1990: Os torques prehistóricos, Santiago.

CASTRO PÉREZ, L. e ESTÉVEZ CRUZ, N., 2003: «El relieve castreño de Formigueiros», Minius 11, 51-64.

CHAMOSO LAMAS, M, 1953: «El castro de San Torcuato (Orense)», Cuadernos de Estudios Gallegos 8, 295-7.

CHAMOSO LAMAS, M., 1954-55: «Excavaciones arqueológicas en la citania de San Cibrán das Lás y en el poblado y explotación minera de oro de época romana de Barbantes (Orense)», Noticiario Arqueológico Hispánico III-IV, 114-30, lám. CXII-CXXXIV.

ESTÉVEZ CRUZ, N., 2002: «O monumento tipo sauna da «cibdá» de Armea en Santa Mariña de Augas Santas», Historia Nova IX e X. IX e X Congreso de Novos/as Historiadores/as, 2001 e 2002, Santiago, 193-215.

FÁBREGA ÁlVAREZ, P., 2004: Poblamiento y Territorio de la Cultura Castreña en la comarca de Ortegal, serie CAPA 19, Santiago.

FÁBREGA ÁlVAREZ, P., 2005: «Tiempo para el espacio. Poblamiento y Territorio en la Edad del Hierro en la comarca de Ortegal (A Coruña, Galicia)», Complutum 16, 125-48.

FERRO COUSELO, J., 1972: «Una lápida con el onomástico ORIVS», Boletín Auriense 2, 336-7.

FERRO RUIBAL, X. (dir.), 1992: Diccionario dos nomes galegos, Vigo.

GALLEGO DOMÍNGUEZ, O., 1999: As barcas e os barcos de pasaxe da provincia de Ourense no antigo réxime, Boletín Auriense, anexo 24, Ourense.

GARCÍA ÁLVAREZ, M. R., 1953: «Castros de un valle gallego. (Los del Ribero del Avia, Orense)», Zephyrus 4, 75-95.

GARCÍA QUINTELA, M. V. e SANTOS ESTÉVEZ, M., 2000: «Petroglifos podomorfos e investiduras reales célticas: estudio comparativo», Archivo Español de Arqueología 73, 5-26. 
GARCÍA QUINTELA, M. V e SANTOS ESTÉVEZ, M., 2004a: «Alineación arqueoastronómica en A Ferradura (Amoeiro-Ourense)», Complutum 15, 51-74.

GARCÍA QUINTELA, M. V. e SANTOS ESTÉVEZ, M., 2004b: «From Rock Carvings to Celtic Weltanschauung in A Ferradura: A Sanctuary of the Hillfort Culture in Northwest Spain», The Journal of Indo-European Studies 32, 319-36.

GARCÍA QUINTELA, M. V., 2006: Soberanía e santuarios na Galicia castrexa, Noia.

GONZÁLEZ RUIBAL, A, 2003: Arqueología del Primer Milenio en el Noroeste de la Península Ibérica, tese doutoral inédita depositada na Universidade Complutense de Madrid.

INFANTE ROURA, F., REY GARCÍA, J. M., RODRÍGUEZ PUENTES, E. e TALLÓN NIETO, M. J., 2004: O Parque Arqueolóxico da Cultura Castrexa. Bases para a súa formalización. RGPA Cadernos 2, Santiago.

LÓPEZ CUEVILLAS, F., 1951: «Esculturas zoomorfas y antropomorfas de la cultura de los castros», Cuadernos de Estudios Gallegos 6, 177-203.

LÓPEZ CUEVILLAS, F., 1956: «El municipio de Lais», Boletín de la Comisión Provincial de Monumentos Históricos y Artísticos de Orense 18, 190-3.

LÓPEZ CUEVILLAS, F., 1980: «Mitoloxía e historia da paisaxe de Trasalba», en OTERO PEDRAYO, R., Florentino L. Cuevillas, 129-36, Vigo.

LÓPEZ CUEVILLAS, F. e LORENZO FERNÁNDEZ, J., 1946: «Las habitaciones de los castros», Cuadernos de Estudios Gallegos 2, 7-74.

LÓPEZ CUEVILLAS, F. e LORENZO FERNÁNDEZ, J., 1952: «Cuatro peñas con pilas, del sur de Galicia», Cuadernos de Estudios Gallegos 7, 5-54.

LORENZO FERNÁNDEZ, J. e GARCÍA ÁLVAREZ, M. R., 1950: «San Ginés de Francelos», Cuadernos de Estudios Gallegos 15, 345-91.

OTERO PEDRAYO, R., 1927-1928: «Probremas de xeografía galega. Notas en col das formas de poboazón labrega. Parroquia de Trasalba», Nós 46 (15-10-1927), 2-9; 48 (15-12-1927), 4-7; 49 (15-1-1928), 2-7; 51 (15-3-1928), 48-53; 52 (15-4-1928), 66-71; 53 (15-5-1928), 95-100 (ed. facs., 1979, Vigo).

OTERO PEDRAYO, R., 1974: «Amoeiro, Os Chaos de», Gran Enciclopedia Gallega 2, 60-2.

OTERO PEDRAYO, R., 1976: «Algunas informaciones sobre creencias del agro gallego sobre la muerte y el más allá», Revista de Dialectología y Tradiciones Populares 32, 405-9.

OTERO PEDRAYO, R., 1980: Florentino L. Cuevillas, Vigo.

PARCERO OUBIÑA, C., 2001: La construcción del paisaje social en la Edad de Hierro del Noroeste Ibérico, tese doutoral inédita depositada na Universidade de Santiago de Compostela.

PARCERO OUBIÑA, C. e FÁBREGA ÁLVAREZ, P., 2006: «Diseño metodológico para el análisis locacional de asentamientos a través de un SIG de base raster», Actas del Congreso Territorios Antiguos y Nuevas Tecnologías. La aplicación de los SIG en la Arqueología del Paisaje (Alicante, 2004), Alicante.

PARCERO OUBIÑA, C., CRIADO BOADO, F. e SANTOS ESTÉVEZ, M., 1998: «La arqueología de los espacios sagrados», Arqueología Espacial 19-20, 507-16.

RIVAS FERNÁNDEZ, J. C., 1972: «La capilla de San Xiao de Fontefría y su ara votiva a los Lares Viales», Boletín Auriense 2, 303-11. 
RIVAS FERNÁNDEZ, J. C., 2003: «Noticia de restos prerrománicos en dos antiguos recintos sagrados ourensanos», Boletín Auriense 33: 209-41.

RODRÍGUEZ COLMENERO, A., 1977: Galicia meridional romana, Madrid.

SANTOS ESTÉVEZ, M. e GARCÍA QUINTELA, M. V., 2000: «Petroglifos podomorfos del noroeste peninsular. Nuevas comparaciones e interpretaciones», Revista de Ciências Hisóricas 15, 7-37.

SANTOS ESTÉVEZ, M., PARCERO OUBIÑA, C. e CRIADO BOADO, F., 1997: «De la arqueología simbólica del paisaje a la arqueología de los espacios sagrados», Trabajos de Prehistoria 55, 73-88.

SANTOS ESTÉVEZ, M. e SEOANE VEIGA, Y., 2004: «Escavación no contorno dun petroglifo en A Ferradura (Ourense-Galiza)», Arkeos 15, 37-54.

SASTRE, I., 2004: La epigrafía de Las Médulas. Escritura y sociedad, Cuadernos de la Fundación Las Médulas, 4, Las Médulas.

SEARA CARBALLO, A., 2002: «Dous baixorrelevos castrexos atopados en Formigueiros (Amoeiro)», Porta da Aira 9, 143-7.

TARACENA, B., 1943: «Cabezas-trofeo en la España céltica», Archivo Español de Arqueología 16, 157-71.

VILLA VALDÉS, A., e CABO PÉREZ, L., 2003: «Depósito funerario y recinto fortificado de la Edad del Bronce en el castro del Chao Sanmartín», Trabajos de Prehistoria, 60 (2), 143-51.

VORÁGINE, S. de la, 1982: La leyenda dorada 1, tr. José Manuel Macías, Madrid. 
